\title{
Comparative wood anatomy of Andromedeae s.s., Gaultherieae, Lyonieae and Oxydendreae (Vaccinioideae, Ericaceae s.l.)
}

\author{
FREDERIC LENS*, ERIK SMETS and STEVEN JANSEN \\ Laboratory of Plant Systematics, K.U.Leuven, Institute of Botany and Microbiology, Kasteelpark Arenberg \\ 31, B-3001 Leuven, Belgium
}

Received May 2003; accepted for publication July 2003

\begin{abstract}
The wood anatomical structure of 11 out of 13 genera from four tribes of the Vaccinioideae, namely Andromedeae s.s., Gaultherieae, Lyonieae and Oxydendreae (Ericaceae s.l.), is described using light and scanning electron microscopy. Several features of the secondary xylem support the tribal classification based on molecular data: arrangement of vessel-ray pitting, height of multiseriate rays and the shape of the body ray cells. Oxydendreae are clearly defined from the other representatives by various wood anatomical features. Gaultherieae can be distinguished from Lyonieae by differences in vessel perforation plates, vessel-ray pitting, height and structure of multiseriate rays, and occurrence of prismatic crystals, but the wood of Andromedeae s.s. is similar to Gaultherieae. Moreover, Andromedeae s.s., Oxydendreae and Vaccinieae are characterized by their pith structure, whereas considerable variation in the pith cells is found in Lyonieae and Gaultherieae. (C) 2004 The Linnean Society of London, Botanical Journal of the Linnean Society, 2004, 144, 161-179.
\end{abstract}

ADDITIONAL KEYWORDS: Andromedeae sensu Stevens - pith structure.

\section{INTRODUCTION}

Andromedeae s.s., Gaultherieae, Lyonieae and Oxydendreae are four tribes of Vaccinioideae (Ericaceae) sensu Kron et al. (2002) comprising about 13 genera and 325 species. All representatives are evergreen shrubs or small trees, which occur in a wide range of geographical areas, ranging from the arctic and temperate regions of the Northern hemisphere to the tropical regions of the Old and New World.

The genera included in the four tribes were previously grouped in the Andromedeae sensu Stevens (1971). The tribe Andromedeae was erected by de Candolle in 1839 and initially comprised 13 genera (Table 1). Hooker (1876) distinguished four subgroups within Andromedeae, without giving them any rank. Drude (1897) divided the group into two tribes, Andromedeae and Gaultherieae, both belonging to the subfamily Arbutoideae (Ericaceae). A significant tax-

*Corresponding author. E-mail: frederic.lens@ bio.kuleuven.ac.be onomic contribution to the group was presented by Stevens $(1970,1971)$, who did not consider the Gaultherieae as a separate tribe. This author placed the Andromedeae next to the tribes Enkiantheae, Cassiopeae and Vaccinieae in the subfamily Vaccinioideae. On the basis of the indumentum, stamen morphology, seed and phloem anatomy, type of stomata and cytological studies, he distinguished two well-defined groups within Andromedeae, namely the Lyoniagroup and the Gaultheria-group. The three remaining genera (Andromeda, Chamaedaphne and Oxydendrum) were considered to be isolated within the tribe. More recently, however, Stevens (1995) doubted the monophyly of the Andromedeae sensu 1971, because there were no obvious morphological synapomorphies that defined the group. Furthermore, molecular data clearly demonstrated that the study group is a paraphyletic association of genera (Kron, Judd \& Crayn, 1999). The most recent classification of Ericaceae, based on molecular as well as morphological data, showed that the Andromedeae sensu Stevens fall apart into four well-supported tribes that form together with Vaccinieae the subfamily Vaccinioideae 
Table 1. Historical overview of the study group according to the classifications of de Candolle (1839), Hooker (1876), Drude (1897), Stevens (1971) and Kron et al. (2002). Genera in bold type are represented in this study

\begin{tabular}{|c|c|c|c|c|}
\hline de Candolle (1839) & Hooker (1876) & Drude (1897) & Stevens (1971) & Kron et al. (2002) \\
\hline ANDROMEDEAE & ANDROMEDEAE & ANDROMEDEAE & ANDROMEDEAE & ANDROMEDEAE \\
\hline Andromeda & Diplycosia & Agarista & LYONIA-GROUP & Andromeda \\
\hline Cassandra & Gaultheria & Agauria & Agarista & Zenobia \\
\hline Cassiope & & Cassiope & Agauria & GAULTHERIEAE \\
\hline Clehtra & Cassiope & Chamaedaphne & Craibiodendron & Chamaedaphne \\
\hline Diplycosia & Chamaedaphne & Epigaea & Lyonia & Eubotrys \\
\hline Elliottia & Epigaea & Leucothoe & Pieris & $\begin{array}{l}\text { Gaultheria } \text { (incl. } \\
\text { Pernettya, Diplycosia) }\end{array}$ \\
\hline Epigaea & Leucothoe & Lyonia & GAULTHERIA-GROUP & Leucothoe \\
\hline Gaultheria & Orphanidesia & Orphanidesia & Diplycosia & Pernettyopsis \\
\hline $\begin{array}{l}\text { Leucothoe (incl. } \\
\text { Agauria, Agarista) }\end{array}$ & Oxydendrum & Oxydendrum & Leucothoe & Tepuia \\
\hline Lyonia & & Pieris & Gaultheria & LYONIEAE \\
\hline Oxydendrum & Agauria & Zenobia & Pernettyopsis & Agarista (incl. Agauria) \\
\hline Pieris & Agarista & GAULTHERIEAE & Tepuia & Craibiodendron \\
\hline \multirow[t]{6}{*}{ Zenobia } & Lyonia & Chiogenes & Zenobia & Lyonia \\
\hline & & Diplycosia & & Pieris \\
\hline & Andromeda & Enkianthus & Andromeda & OXYDENDREAE \\
\hline & Enkianthus & Gaultheria & Chamaedaphne & Oxydendrum \\
\hline & Pieris & Pernettya & Oxydendrum & \\
\hline & Zenobia & Wittsteinia & & \\
\hline
\end{tabular}

(Kron et al., 2002). The monospecific Oxydendreae is sister to the rest of the Vaccinioideae. Lyonieae, including all members of the Lyonia-group of Stevens (1970), forms a clade that is sister to Vaccinieae and a clade containing the sister tribes Andromedeae s.s. and Gaultherieae (for further details, see Figs 44-49).

The most important wood anatomical work of the study group was presented by Cox (1948), who studied six genera, namely Agarista (incl. Agauria), Andromeda, Chamaedaphne, Gaultheria (incl. Pernettya, Diplycosia and Chiogenes), Leucothoe and Oxydendrum. His observations were based on narrow twigs of herbarium material and the wood anatomical descriptions presented were not very detailed. Metcalfe \& Chalk (1950) presented a more complete description in their family treatment, with comments on the genera Agauria, Andromeda, Craibiodendron, Gaultheria (incl. Pernettya), Lyonia and Oxydendrum. Furthermore, Suzuki \& Noshiro (1988) described the wood structure of Lyonia and Pieris. A special feature that has been reported so far in a limited number of woody dicots includes the presence of a living protoplast in libriform fibres. These living fibres were also observed in few Vaccinieae species, but the distribution of this feature requires further observations (Braun, 1961; Fahn \& Leshem, 1962; Luteyn, 1983).

The above-mentioned studies indicate that a detailed wood anatomical survey of the group is lack- ing. Therefore, this paper presents data on the wood anatomy of all genera of the Andromedeae s.s., Gaultherieae, Lyonieae and Oxydendreae recognized by Kron et al. (2002), except for Eubotrys and Pernettyopsis. The variation in the secondary xylem observed is evaluated according to molecular phylogenetic insights in order to reveal possible evolutionary patterns in the wood and to comment on the classification. In addition, we attempt to demonstrate the distribution of living fibres and the results obtained are compared with related taxa within Ericaceae s.l. This study is part of a general wood anatomical survey of Vaccinioideae. An ecological approach to the wood anatomy of this subfamily will be treated elsewhere. As has already been illustrated by Stevens (1971), Judd (1979) and Kron et al. (1999), there is also a significant variation in the pith structure of the study group, which will also be investigated here.

\section{MATERIAL AND METHODS}

Wood samples of 55 specimens representing 38 species and 11 genera were investigated using LM and SEM. The wood anatomical terminology follows the 'IAWA list of microscopic features for hardwood identification' (IAWA, 1989). When distinctly bordered vesselray pits are mentioned, we actually mean that the pit pairs are half-bordered, because the pit on the paren- 
chyma cell side is simple and that on the vessel side is bordered.

Wood sections of about $25 \mu \mathrm{m}$ were cut using a sledge microtome. After bleaching, staining and dehydrating, the tissues were mounted in euparal. Preparations for macerations and SEM were prepared according to Jansen et al. (1998). Nuclei in living fibres were stained using acetocarmine.

All types of non-perforated tracheary elements, namely tracheids, fibre-tracheids and libriform fibres, are present in the wood of Ericaceae s.l. (Baas, 1979; Carlquist, 1988; Lens et al., 2003). Accordingly, it may be rather arbitrary to allocate intermediate cell types to one of these categories. Furthermore, the circumscription of tracheids, fibre-tracheids and libriform fibres still remains a matter of dispute (Baas, 1986; Carlquist, 2001). Therefore, we prefer to give a detailed description of these cells. We define tracheids to be long and narrow cells, with dense pitting in both tangential (c. more than 15 pits per $100 \mu \mathrm{m}$ of tracheid length) and radial walls (c. more than 20 pits per $100 \mu \mathrm{m}$ of tracheid length). These pits are distinctly bordered and form two or three longitudinal rows in the radial and tangential walls. Tracheids are rather sparse and randomly distributed within a growth ring. Fibre-tracheids represent the most common cell type of the ground tissue and are abundantly present throughout a growth ring. They are somewhat longer than tracheids, narrow, thin- or thick-walled, and contain a single row of distinctly bordered pits in the tangential walls $(c .5-15$ pits per $100 \mu \mathrm{m}$ of fibre-tracheid length) and radial walls (c. 8-20 pits per $100 \mu \mathrm{m}$ of fibre-tracheid length). The mean distance between two fibre-tracheid pits in the tangential wall is longer than the distance between two tracheid pits, although the pit borders do not differ in size $(c .3-6 \mu \mathrm{m})$. Libriform fibres are sparsely scattered within a growth ring. They are narrow, thin- or thick-walled, generally as long as fibre-tracheids, mostly septate, and show few to very few, indistinctly bordered pits (sometimes also simple pits) in the tangential walls. The pit borders in the libriform fibres are $2-3 \mu \mathrm{m}$ in size and their density ranges from less than one to four per $100 \mu \mathrm{m}$ of length in tangential walls, and from two to about ten per $100 \mu \mathrm{m}$ of length in radial walls. Sometimes, only two or three pits are observed at the tails of libriform fibres. For all measurements of tracheary elements, 25 clearly identifiable cells from maceration slides were taken into account.

The wood samples studied are listed below with reference to the origin, collector and the diameter of the wood sample. Pernettya and Diplycosia, now included in Gaultheria, as well as Agauria, now included in Agarista, are described separately to investigate whether their inclusion is wood anatomically justified. 'Mature' means that the wood sample is derived from a mature stem, although the exact diameter could not be traced. An asterisk indicates that the wood sample is preserved in FAA to trace possible nuclei in the libriform fibres. Institutional wood collections used in this study are abbreviated according to the Index Xylariorum (Stern, 1988). Other institutions that were used to collect wood samples are The National Botanic Garden of Belgium (BR), The Royal Botanic Garden, Edinburgh (E) and The New York Botanical Garden (NY).

Agarista bracamorensis G.Don: Peru (Cajamarca), J.L. Luteyn, I. Sánchez-Vega \& M. Zapata 15538, $9 \mathrm{~mm}$; Agarista duckei (Huber) Judd: Venezuela (Amazonas), B. Maguire et al. 42692 ( $\mathrm{Tw} 36848$ ), $58 \mathrm{~mm}$; Agarista eucalyptoides (Cham. \& Schltdl.) G.Don: Brazil, G.G. Hatschbach \& J.C. Lindeman 20935 (Uw 20844), $70 \mathrm{~mm}$; Agarista organensis (Gardner) Nied. Brazil, A. Glaziou 2878 (BR), 7 mm; Agarista populifolia (Lam.) Judd: origin and collector unknown (E 19571017), 8 mm; Agarista pulchella G.Don: Brazil, R. Kummrow 2048 (BR), 8 mm; Agarista uleana (Sleumer) Judd: Brazil, A. Glaziou 3048, $8 \mathrm{~mm}$; Agauria salicifolia Oliv.: Eastern Africa, H.-J. Schlieben \& Reinbek 1505 (U 15488), 90 mm; Agauria salicifolia Oliv.: Rwanda, G. Bouxin 877 (Tw 24171), mature; Andromeda polifolia L.*: Belgium (BR), F. Lens, $4.5 \mathrm{~mm}$; Chamaedaphne calyculata Moench: Germany, E. Smets, Botanical Garden of Bochum (Germany), $5 \mathrm{~mm}$; Craibiodendron stellatum W.W.Sm.: Thailand (Tunkamang), C.F. Van Beusekom \& R. Geesink 4361 (L.), 57 mm; Diplycosia heterophylla Blume: Indonesia (Java, Gunong Pangrango), P. Woods 1046 (E 19680830), $9 \mathrm{~mm}$; Gaultheria anastomosans (L.) H.B.K.: Colombia (Cauca), J.L. Luteyn, R. Callejas \& J.J. Pipoly 10085, 27 mm; Gaultheria buxifolia Willd. var. buxifolia: Venezuela (Mérida, near Santo Domingo), J.L. Luteyn, M. Lebrón-Luteyn, L. Ruiz-Teran \& J.A. Dugarte 5237, $14 \mathrm{~mm}$; Gaultheria buxifolia Willd. var. buxifolia: Venezuela (Trujillo), J.L. Luteyn, M. Lebrón-Luteyn, L. Ruiz-Teran \& J.A. Dugarte 5195, $18 \mathrm{~mm}$; Gaultheria buxifolia Willd. var. ellasantha (A.C.Sm.) Luteyn: Colombia (Antioquia), J.L. Luteyn \& M. Lebrón-Luteyn 7079, 13 mm; Gaultheria buxifolia Wildd. var. secunda (J.Remy) Luteyn: Peru (Cuzco), J.L. Luteyn \& M. Lebrón-Luteyn 6376, 8 mm; Gaultheria erecta Vent.: Ecuador (Carchi), J.L. Luteyn \& M. Lebrón-Luteyn 5739, $8 \mathrm{~mm}$; Gaultheria erecta Vent.: Venezuela, Wagener (Kw 11654), 26 mm; Gaultheria erecta Vent.: Venezuela (Tachira), J.L. Luteyn, M. Lebrón-Luteyn \& L. Ruiz-Teran 6020, 8 mm; Gaultheria eriophylla (Persoon) Burtt. var. mucronata (J.Remy) Luteyn: Peru (Cuzco), J.L. Luteyn \& M. Lebrón-Luteyn 6375, $10 \mathrm{~mm}$; Gaultheria reticulata H.B.K.: Ecuador (Azuay), J.L. Luteyn \& E. Cotton 11158, $18 \mathrm{~mm}$; Gaultheria rigida H.B.K: Colombia, A.M. Cleef 2799 (Uw 20769), 9 mm; Gaultheria rudis 
Stapf: Sri Lanka, H.P. Nooteboom 3342 (L), 9 mm; Gaultheria shallon Pursh: USA (Oregon), R. Dechamps 4308 (Tw 45992), 7 mm; Gaultheria shallon Pursh*: Belgium (BR), F. Lens, 6.5 mm; Gaultheria strigosa Benth. var. strigosa: Colombia (Antioquia), J.L. Luteyn \& M. Lebrón-Luteyn 7101, 10 mm; Gaultheria strigosa Benth. var. strigosa: Ecuador (Azuay), J.L. Luteyn \& M. Lebrón-Luteyn 5777, 12 mm; Gaultheria tomentosa H.B.K.: Peru (Amazonas, Chachapoyas), J.L. Luteyn \& M. Lebrón-Luteyn 5569, 13 mm; Leucothoe axillaris D.Don: USA (Georgia), collector unknown (E 19881623), $13 \mathrm{~mm}$; Leucothoe fontanesiana (Steud.) Sleumer*: Belgium (BR), F. Lens, $5 \mathrm{~mm}$; Leucothoe grayana Maxim.: origin and collector unknown (E 19080096), $13 \mathrm{~mm}$; Lyonia ferruginea Nutt.: USA (Florida), A. Curtis (Tw 53206), mature; Lyonia ferruginea Nutt.: USA, A. Curtis 60 (Kw 11721), 110 mm; Lyonia heptamera Urb.: Dominican Republic, J. Pimentel \& M. Mejia 993 (MADw 49103), $31 \mathrm{~mm}$; Lyonia jamaicensis D.Don: Jamaica, World Colombian Exposition 14997 (MADw 3549), mature; Lyonia lucida C.Koch: USA, C.D. Mell (MADw 2951), $22 \mathrm{~mm}$; Lyonia ovalifolia (Wall.) Drude: India (Punjab), Birla Institute of Scientific Research (Tw 45182), mature; Lyonia ovalifolia (Wall.) Drude: Japan (Kumamoto), For. Exp. Stat. 2244 (Tw 17276), mature; Lyonia ovalifolia (Wall.) Drude: Japan, R.E. Regel (Kw 11670), $135 \mathrm{~mm}$; Lyonia ovalifolia (Wall.) Drude: India, W. Gamble (Kw 11667); mature; Lyonia squamulosa M.Martens \& Galeotti: Mexico, D. Breedlove 9683 (MADw 23903), 23 mm; Oxydendrum arboreum (L.) DC.: USA (Ohio), A.W. Green 245 (Tw 19787), mature; Oxydendrum arboreum (L.) DC.: USA, J.C. Ward 19 (MADw 4550), mature; Oxydendrum arboreum (L.) DC.: USA, J.L. Stearns 137 (MADw 9551), mature; Pernettya mucronata (L.f.) A.Spreng.: The Netherlands, A.M.W. Mennega (UN 835), 13 mm; Pernettya mucronata (L.f.) A.Spreng. var. angustifolia (Lindl.) Reiche: Argentina (Rio Negro), P. Dezarbo 433 (BR), 8 mm; Pernettya rigida DC.: Chili (Juan Fernandez Islands), Meyer 9490 (Uw 14995), 66 mm; Pieris formosa D.Don: India (Meghalaya), Birla Institute of Scientific Research (Tw 45532), mature; Pieris japonica (Thunb.) G.Don*: Belgium (BR), F. Lens, 8 mm; Pieris japonica (Thunb.) G.Don: Greece (Crete), L. Rothkegel (BR), $7 \mathrm{~mm}$; Tepuia venusta Camp: Venezuela (Bolivar), O. Huber 8581, 2.5 mm; Zenobia pulverulenta Pollard*: Belgium (BR), F. Lens, $7 \mathrm{~mm}$; Zenobia pulverulenta Pollard: origin and collector unknown (E 19721932), $10 \mathrm{~mm}$.

\section{RESULTS}

The material studied is described according to the classification of Kron et al. (2002). For each genus examined the nominator gives the number of species studied and the denominator includes the total number of species. Numbers in parentheses are mean values. A summary of the results is presented in Table 2.

\section{OXYDENDREAE (OXYDENDRUM 1/1; FIGS 1-8)}

Growth ring boundaries distinct. Wood usually diffuse-porous, sometimes tendency to semi-ring-porosity. Vessels exclusively solitary or sometimes in small tangential (exceptionally radial) groupings, vessel outline rounded. Vessel perforation plates largely simple, sometimes scalariform with 2-(4)-7 bars. Intervessel pits opposite, 4-6 $\mu \mathrm{m}$ in size, to scalariform, 4-15 $\mu \mathrm{m}$ in size, non-vestured. Vessel-ray pits mostly scalariform, mainly distinctly bordered but sometimes also simple, $8-15 \mu \mathrm{m}$ in size. Helical sculpturing present throughout body of vessel elements. Tangential diameter of vessel lumina 25-(39)-55 $\mu \mathrm{m}, 104-(151)-205$ vessels $\mathrm{mm}^{-2}$, vessel elements $320-(521)-800 \mu \mathrm{m}$ long. Tracheids present, 430-(615)-750 $\mu \mathrm{m}$ in length. Fibre-tracheids with distinctly bordered pits, 3-4 $\mu \mathrm{m}$ in diameter, thin- to thick-walled, and 620-(978)$1500 \mu \mathrm{m}$ long. Occasionally libriform fibres with few simple to indistinctly bordered pits, septate, 350-(577)-780 $\mu \mathrm{m}$ long. Axial parenchyma scanty paratracheal, 2-4 cells per parenchyma strand. Uniseriate rays always present, $80-(145)-300 \mu \mathrm{m}$ high, consisting of upright cells, $0-(2)-4$ rays $\mathrm{mm}^{-1}$. Multiseriate rays often $2-3$-seriate, up to 4 cells wide in MADw 9551, 0-(2)-4 rays $\mathrm{mm}^{-1}$, consisting of procumbent body ray cells and 1-2 upright marginal ray cells, sheath cells absent. Gummy deposits in ray cells. Prismatic crystals present in axial parenchyma. Pith not seen.

\section{LYONIEAE (AGARISTA 7/30, AGAURIA 1/1, CRAIBIODENDRON 1/5, LYONIA 8/36, PIERIS 3/7; FIGS 9-26)}

Growth ring boundaries distinct or indistinct. Usually diffuse-porous, but sometimes tendency to semi-ringporosity in Agarista uleana, Lyonia ferruginea, L. heptamera, L. ovalifolia and in Pieris japonica. Vessels exclusively solitary, sometimes in small tangential and/or radial groupings in Agauria salicifolia, Lyonia ferruginea, L. ovalifolia and Pieris formosa; vessel outline angular, exceptionally rounded in Lyonia jamaicensis. Vessel perforation plates mostly scalariform, 1-(15)-59 bars, sometimes mixed scalariform and simple in Lyonia ovalifolia Kw 11667 (90\% scalariform), Craibiodendron stellatum (85\% scalariform), Pieris japonica (80-50\% scalariform) and Agauria (30-25\% scalariform); perforations exclusively simple in Lyonia jamaicensis; sometimes a small percentage of irregular perforations in Craibiodendron stellatum. Intervessel pits mainly opposite to 

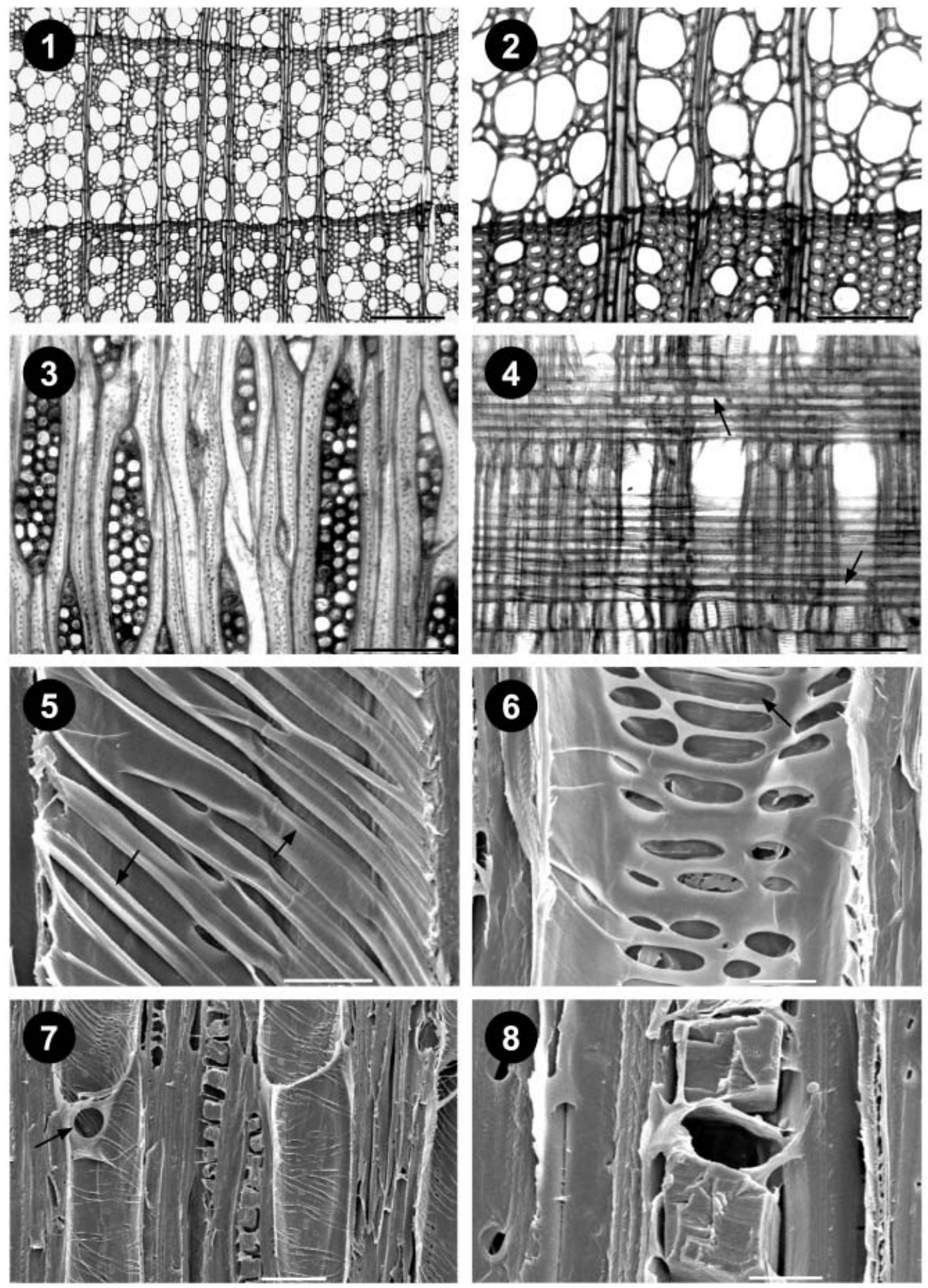

Figures 1-8. LM and SEM micrographs showing the wood structure in Oxydendrum arboreum. Fig. 1. TS, tendency to semi-ring-porosity with distinct growth rings, overview. Scale bar $=200 \mu \mathrm{m}$. Fig. 2 . TS, idem, detail. Scale bar $=100 \mu \mathrm{m}$. Fig. 3. TLS, short, multiseriate rays. Scale bar $=100 \mu \mathrm{m}$. Fig. 4. RLS, procumbent body ray cells (arrows). Scale bar $=100 \mu \mathrm{m}$. Fig. 5. TLS, helical thickenings on the inner vessel element wall (arrows). Scale bar $=10 \mu \mathrm{m}$. Fig. 6 . RLS, simple, scalariform vessel-ray pitting (arrow). Scale bar $=10 \mu \mathrm{m}$. Fig. 7. RLS, simple vessel perforation (arrow), prismatic crystals in chambered axial parenchyma cells. Scale bar $=50 \mu \mathrm{m}$. Fig. 8 . RLS, detail of prismatic crystals in chambered axial parenchyma cells. Scale bar $=10 \mu \mathrm{m}$. 


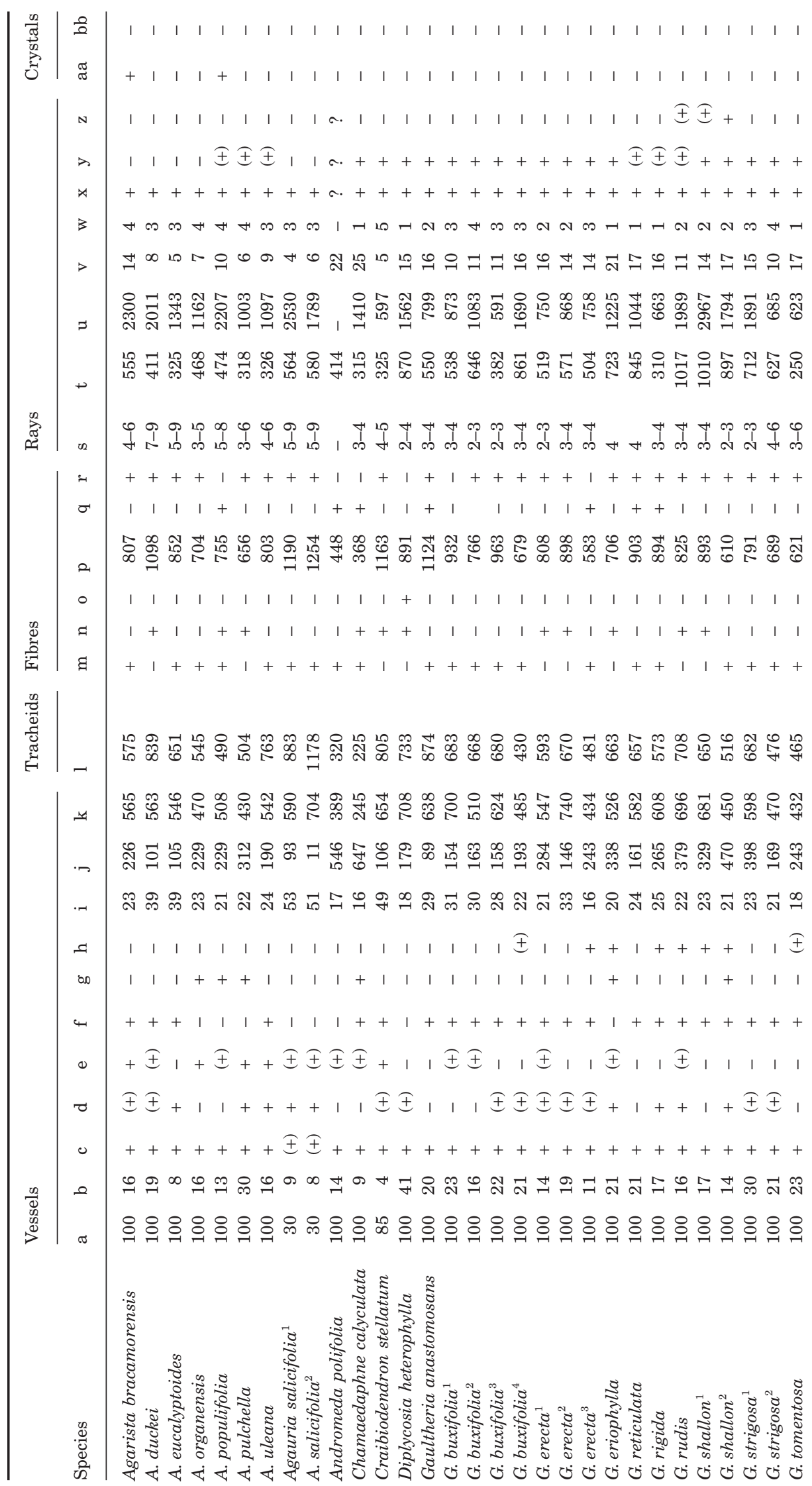




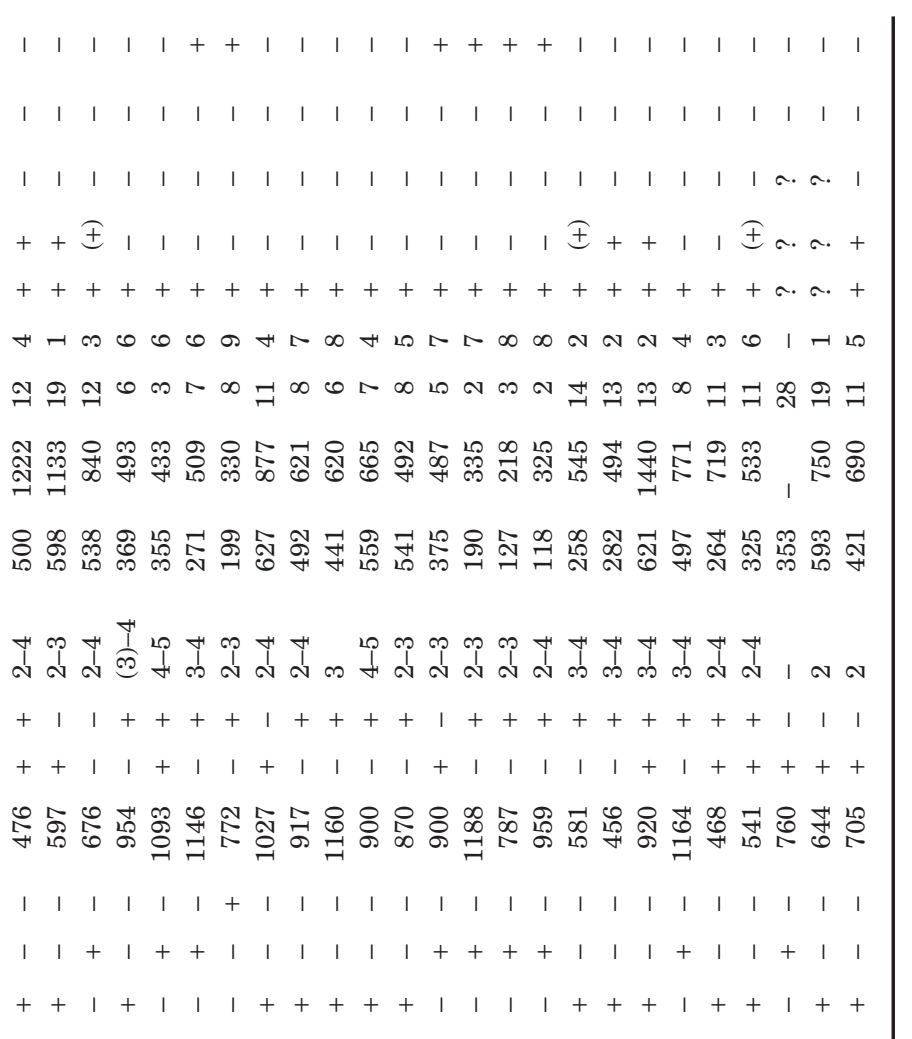

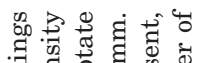

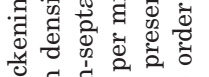

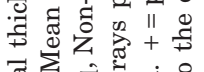

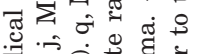

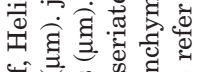

边

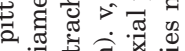

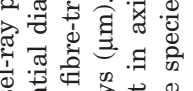

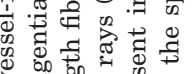

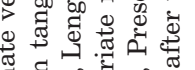

สี

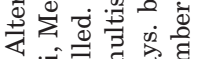

ब. त त्व द्व

of

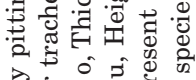

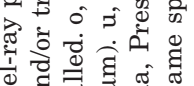

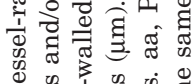

势

घ을

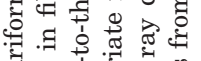

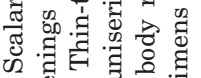

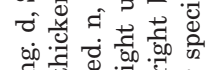

की

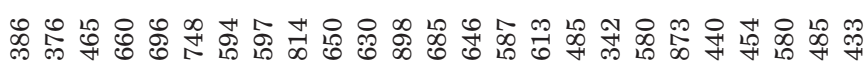

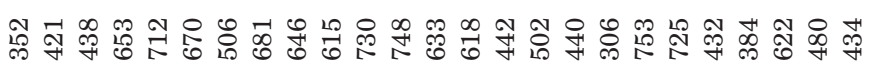

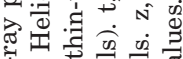

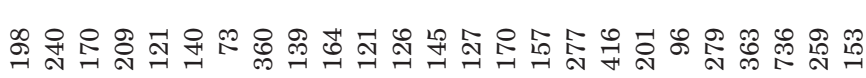

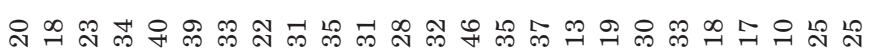

$\begin{array}{lllllllllllllllll}1 & 1 & 1 & 1 & 1 & 1 & 1 & 1 & 1 & 1 & 1 & 1 & 1 & 1 & 1 & 1 & 1 \\ 1 & 1 & + & 1 & 1 & 1 & 1 & 1 & 1\end{array}$

$1|1+++1+1| 1 \mid 1++++1+11++111$

$1,1 \pm+1|1| 1|++1| 1 \mid 1+1+++1+1$ I

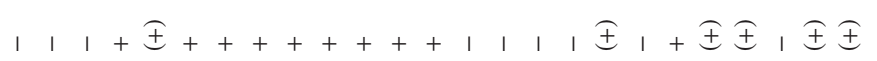

$1|1|+|1|_{1}|1| 1|++\mp 1| £+++1 \mid$

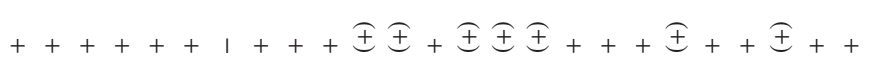

곡

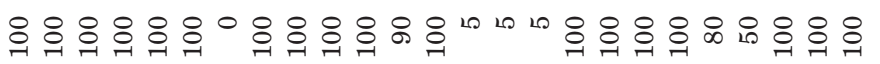

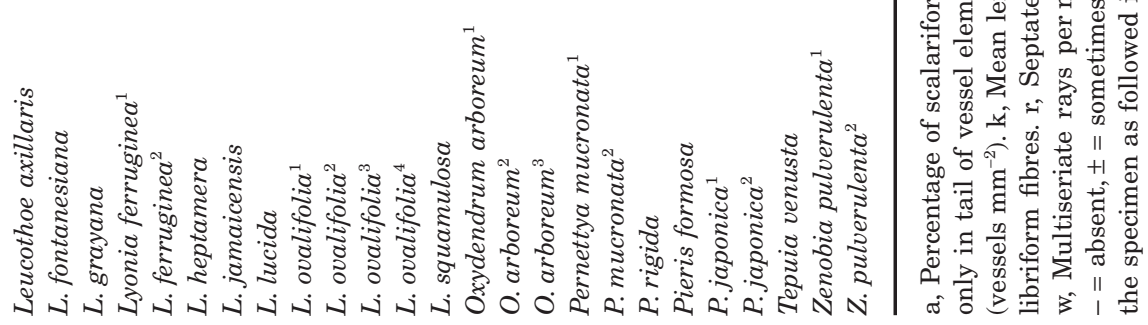



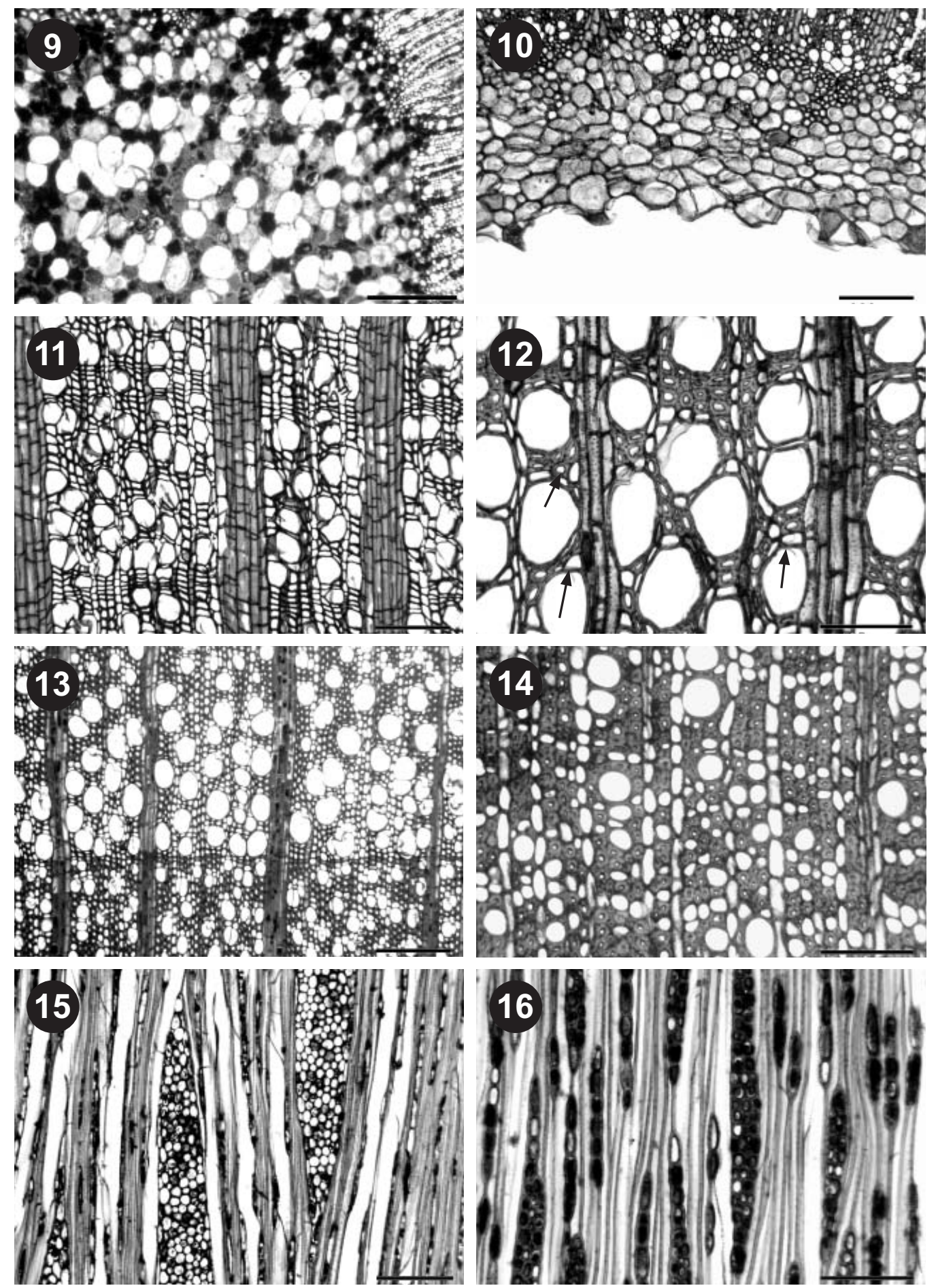

Figures 9-16. LM micrographs showing transverse and tangential sections of Lyonieae wood samples. Fig. 9. Pieris japonica, heterogeneous pith. Scale bar $=200 \mu \mathrm{m}$. Fig. 10. Agarista populifolia, TS, Calluna-pith type showing a pith cavity at the bottom. Scale bar $=200 \mu \mathrm{m}$. Fig. 11. Agauria salicifolia, TS, solitary vessels and wide, multiseriate rays. Scale bar $=200 \mu \mathrm{m}$. Fig. 12. Craibiodendron stellatum, TS, wide, solitary vessels, scanty paratracheal parenchyma (arrows). Scale bar $=100 \mu \mathrm{m}$. Fig. 13. Lyonia ferruginea, TS, tendency to semi-ring-porous wood. Scale bar $=200 \mu \mathrm{m}$. Fig. 14. Lyonia jamaicensis, TS, rounded vessel outlines, thick-walled fibres, diffuse-in-aggregates axial parenchyma. Scale bar $=100 \mu \mathrm{m}$. Fig. 15. Agarista duckei, TLS, wide multiseriate rays. Scale bar $=200 \mu \mathrm{m}$. Fig. 16. Pieris japonica, TLS, uniseriate rays and narrow multiseriate rays containing tannins. Scale bar $=100 \mu \mathrm{m}$. 

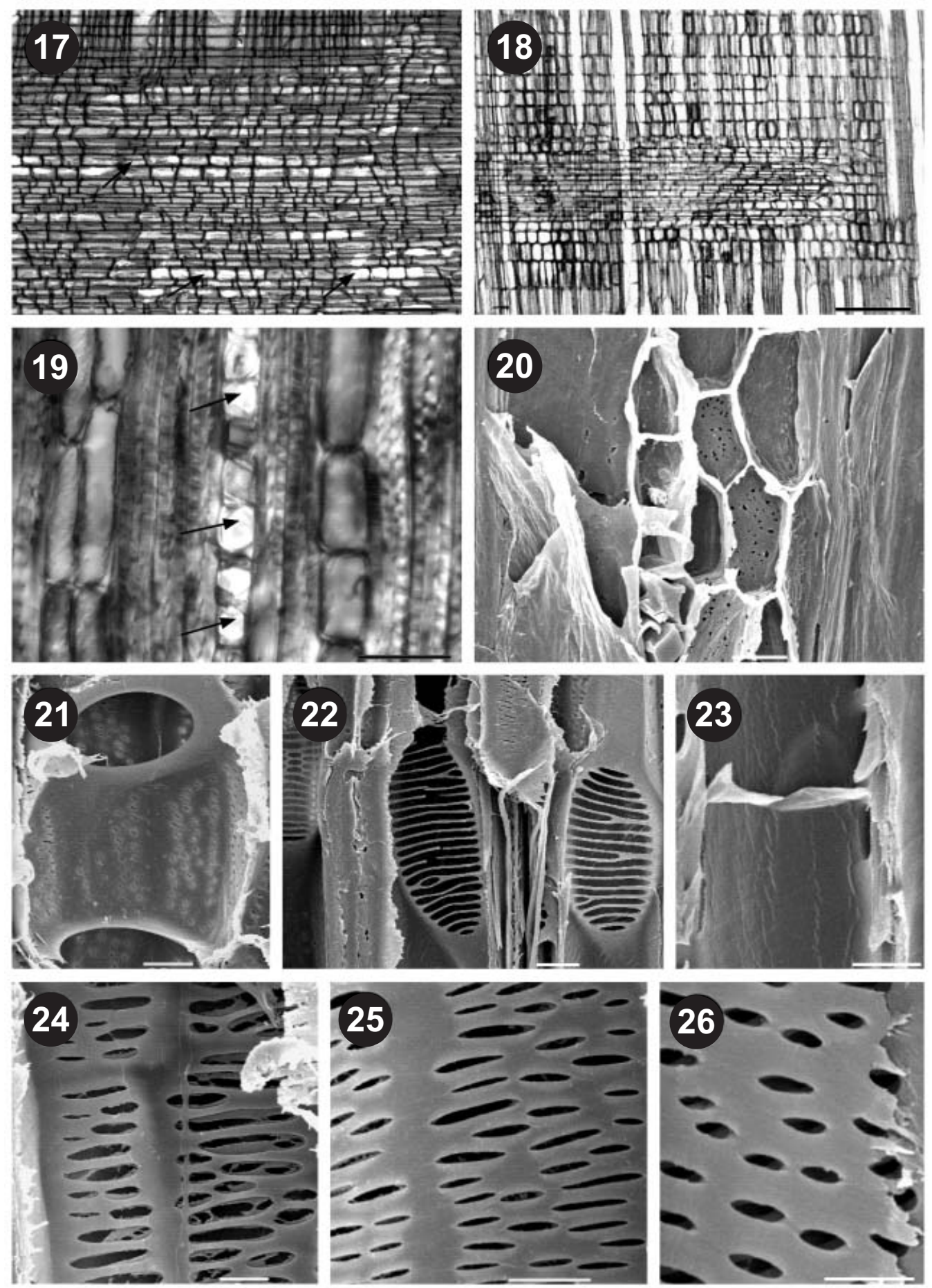

Figures 17-26. LM and SEM micrographs showing the structure of the multiseriate rays, presence of prismatic crystals, vessel perforations, septate fibres and vessel-ray pits. Fig. 17. Agauria salicifolia, RLS, procumbent body ray cells (arrows). Scale bar $=200 \mu \mathrm{m}$. Fig. 18. Lyonia lucida, RLS, idem. Scale bar $=200 \mu \mathrm{m}$. Fig. 19. Lyonia jamaicensis, TLS, prismatic crystals in chambered axial parenchyma cells (arrows). Scale bar $=100 \mu \mathrm{m}$. Fig. 20. Agarista bracamorensis, TLS, prismatic crystals in ray cells. Scale bar $=10 \mu \mathrm{m}$. Fig. 21. Agauria salicifolia, RLS, vessel element with simple perforations. Scale bar $=20 \mu \mathrm{m}$. Fig. 22. Agarista duckei, RLS, scalariform perforations. Scale bar $=20 \mu \mathrm{m}$. Fig. 23. Agarista duckei, TLS, detail of a libriform fibre wall with a septum. Scale bar $=5 \mu \mathrm{m}$. Fig. 24. Agauria salicifolia, RLS, scalariform vessel-ray pits with reduced borders to simple. Scale bar $=10 \mu \mathrm{m}$. Fig. 25. Agarista eucalyptoides, RLS, scalariform to alternate vesselray pitting. Scale bar $=10 \mu \mathrm{m}$. Fig. 26. Lyonia squamulosa, TLS, alternate vessel-ray pitting. Scale bar $=5 \mu \mathrm{m}$. 
alternate in Agarista, Craibiodendron, Lyonia (but exclusively alternate in L.jamaicensis), and Pieris, and opposite to scalariform in Agauria (sometimes alternate); opposite and alternate pitting $3-5 \mu \mathrm{m}$ in size, scalariform pitting 8-20 $\mu \mathrm{m}$, non-vestured. Vessel-ray pits similar to intervessel pits in size and shape, although distinctly bordered scalariform pitting is more abundant; in Agauria reduced to even simple scalariform pits. Helical thickenings present throughout the body of vessel elements or only in vessel element tails, but absent in Agauria and L. jamaicensis. Tangential diameter of vessel lumina 12-(32)-70 $\mu \mathrm{m}, 7-(172)-440$ vessels $\mathrm{mm}^{-2}$, vessel elements $280-(595)-970 \mu \mathrm{m}$ long. Tracheids present, $340-(695)-1450 \mu \mathrm{m}$ in length. Fibre-tracheids with distinctly bordered pits, $3-6 \mu \mathrm{m}$ in diameter, very thin- to thick-walled and $360-(930)-1450 \mu \mathrm{m}$ in length. Occasionally libriform fibres with few simple to indistinctly bordered pits and mostly septate, 350 (650)-1150 $\mu \mathrm{m}$ long; nuclei observed in libriform fibres of Pieris japonica (BR, F. Lens). Axial parenchyma mostly scanty paratracheal, sometimes diffuse-in-aggregates in Lyonia jamaicensis and L. squamulosa, 2-6 cells per parenchyma strand (6-9 cells per strand in Lyonia jamaicensis). Uniseriate rays always present, $80-(422)-1100 \mu \mathrm{m}$ high, consisting only of upright cells, $1-(8)-19$ rays $\mathrm{mm}^{-1}$. Multiseriate rays often $2-5$-seriate, usually up to 9 cells wide in Agarista and Agauria, 1-(5)-11 rays $\mathrm{mm}^{-1}$, consisting of procumbent body ray cells (sometimes also square in some Agarista species) and a variable number of upright or square marginal ray cells, indistinct sheath cells in Agarista, Agauria and Craibiodendron. Gummy deposits in ray cells. Prismatic crystals present in ray cells of Agarista populifolia and in axial parenchyma cells of Lyonia heptamera, L. jamaicensis and $L$. squamulosa. Pith cells of two different forms in Pieris japonica: small groups of larger cells with thin walls clustered between smaller cells with thicker walls; pith cells thin-walled and restricted to the periphery of a pith cavity in Agarista bracamorensis, A. organensis, A.populifolia, A.pulchella and A. uleana. Prismatic crystals in pith cells of Agarista pulchella and A. populifolia.

\section{GaUltherIEAe (CHAMAEDAPHNE 1/1, DIPLYCOSIA} 1/C. 100, GAULTHERIA 12/C. 125, LEUCOTHOE 3/8, PERNETTYA 2/14, TEPUIA 1/7; FIGS 27-37)

Growth ring boundaries indistinct or distinct. Diffuseporous. Vessels mostly solitary, sometimes in small tangential or radial groupings, vessel outline angular. Vessel perforation plates exclusively scalariform, with 4-(18)-57 bars. Intervessel pits mainly opposite, sometimes alternate in Chamaedaphne, Gaultheria, and Pernettya, 2-5 $\mu \mathrm{m}$ in size, non-vestured. Vessel- ray pits opposite, $2-5 \mu \mathrm{m}$ in size, to scalariform, 6-30 $\mu \mathrm{m}$, mainly scalariform in Tepuia, sometimes alternate in Chamaedaphne, Gaultheria and Pernettya, $2-5 \mu \mathrm{m}$ in size. Helical thickenings in Chamaedaphne, Gaultheria, Pernettya and Tepuia, throughout body of vessel elements or only in vessel element tails, but also in fibres and/or tracheids of Gaultheria and Pernettya. Tangential diameter of vessel lumina 7-(21)-45 $\mu \mathrm{m}, 70-(267)-820$ vessels $\mathrm{mm}^{-2}$, vessel elements $170-(537)-1200 \mu \mathrm{m}$ long. Tracheids present, 270-(562)-1050 $\mu \mathrm{m}$ in length. Fibre-tracheids mostly with distinctly bordered pits, $3-6 \mu \mathrm{m}$ in diameter, very thin- to thick-walled, 320-(746)$1400 \mu \mathrm{m}$ in length. Occasionally libriform fibres with few simple to indistinctly bordered pits (except in Diplycosia heterophylla), mostly septate, 220-(624)$1300 \mu \mathrm{m}$ long; nuclei observed in libriform fibres of Gaultheria shallon (BR) and Leucothoe fontanesiana. Axial parenchyma scanty paratracheal, 2-4 cells per parenchyma strand. Uniseriate rays always present, 140-(595)-2750 $\mu \mathrm{m}$ high, consisting only of upright cells, 7-(15)-34 rays $\mathrm{mm}^{-1}$. Multiseriate rays present except for Tepuia, often 2-4-seriate, up to 6 cells wide in Gaultheria strigosa var. strigosa and G. tomentosa, 0-(2)-5 rays $\mathrm{mm}^{-1}$, consisting of procumbent and square body ray cells (sometimes also upright in Gaultheria rudis and G. shallon), and several rows of square or upright marginal ray cells, indistinct sheath cells in Diplycosia, Gaultheria, Leucothoe and Pernettya. Gummy deposits in ray cells. Crystals absent. Pith cells of two different forms in G. buxifolia var. secunda, G. shallon and Pernettya mucronata: larger cells with very thin walls clustered between smaller cells with thicker walls; all pith cells rounded, similar in size, and thin-walled in Chamaedaphne and Tepuia. No prismatic crystals in pith cells observed.

\section{ANDROMEDEAE S.S. (ANDROMEDA 1/2, ZENOBIA 1/1;} FIGS 38-43)

Growth ring boundaries distinct. Diffuse-porous. Vessels solitary with an angular vessel outline. Vessel perforation plates exclusively scalariform, with 8-(12)-22 bars. Intervessel and vessel-ray pits mainly opposite, sometimes alternate, $2-3 \mu \mathrm{m}$ in size, non-vestured. Helical thickenings absent, but sometimes present in vessel element tails of Zenobia pulverulenta (BR). Tangential diameter of vessel lumina $12-(22)-35 \mu \mathrm{m}, 128-(319)-660$ vessels $\mathrm{mm}^{-2}$, vessel elements $270-(434)-620 \mu \mathrm{m}$ long. Tracheids present, 280-(412)-570 $\mu \mathrm{m}$ long. Fibre-tracheids mostly with distinctly bordered pits, $3-5 \mu \mathrm{m}$ in diameter, very thin-walled, 360-(599)-830 $\mu \mathrm{m}$ long. Occasionally libriform fibres with few simple to indistinctly bordered pits, non-septate, 370-(541)-730 $\mu \mathrm{m}$ long; nuclei 

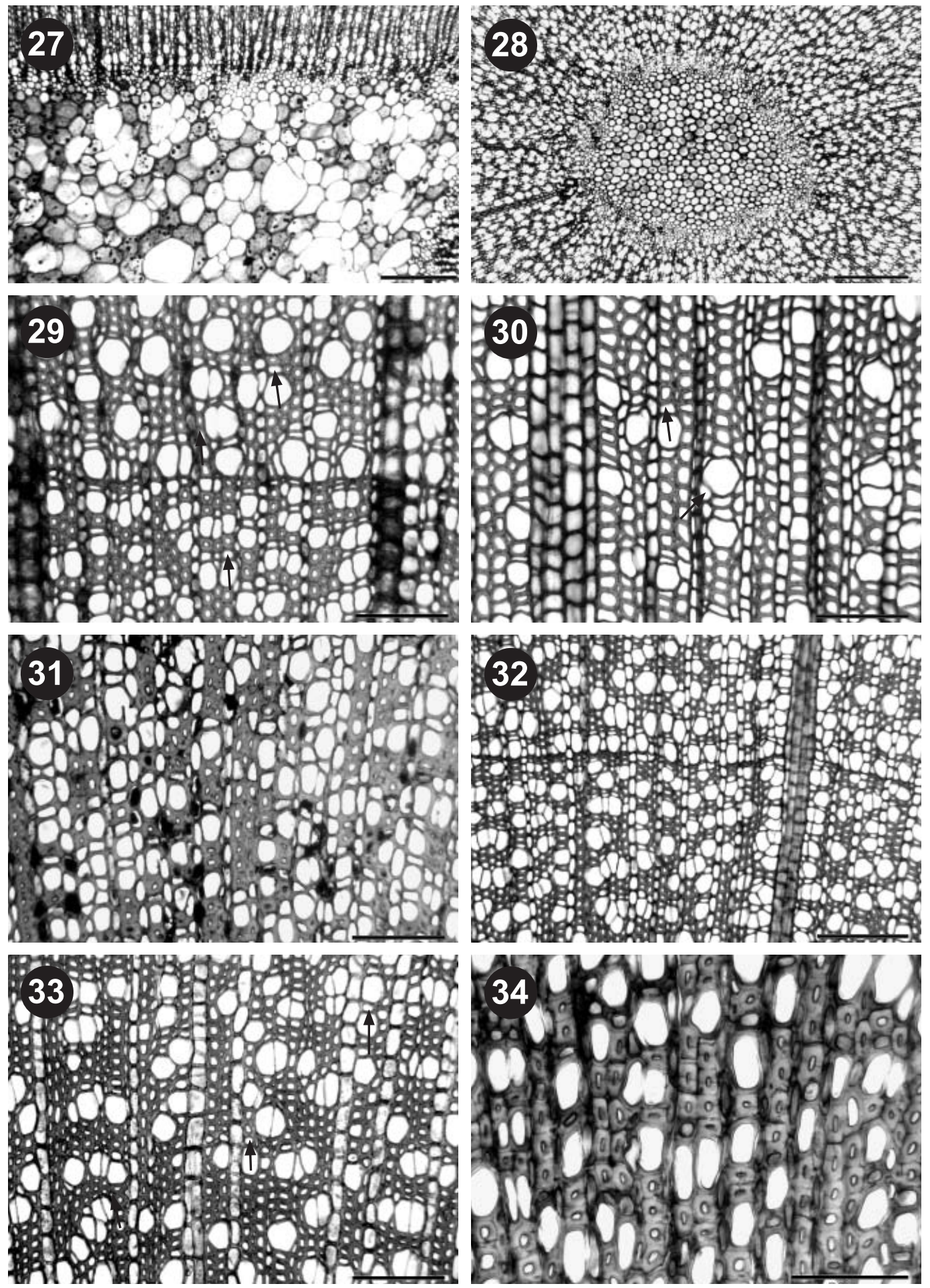

Figures 27-34. LM micrographs showing transverse sections of Gaultherieae wood samples. Fig. 27. Gaultheria buxifolia var. secunda, TS, heterogeneous pith. Scale bar $=200 \mu \mathrm{m}$. Fig. 28. Chamaedaphne calyculata, TS, homogeneous pith. Scale bar $=200 \mu \mathrm{m}$. Fig. 29. Gaultheria shallon, TS, solitary vessels, scanty paratracheal parenchyma (arrows). Scale bar $=100 \mu \mathrm{m}$. Fig. 30. Gaultheria rigida, TS, idem (arrows). Scale bar $=100 \mu \mathrm{m}$. Fig. 31. Diplycosia heterophylla, TS, thickwalled fibres. Scale bar $=100 \mu \mathrm{m}$. Fig. 32. Chamaedaphne calyculata, TS, distinct growth ring, narrow vessels with a high density. Scale bar $=100 \mu \mathrm{m}$. Fig. 33. Leucothoe axillaris, TS, solitary vessels, scanty paratracheal parenchyma (arrows). Scale bar $=100 \mu \mathrm{m}$. Fig. 34. Tepuia venusta, TS, very narrow vessels, thick-walled fibres. Scale bar $=50 \mu \mathrm{m}$. 

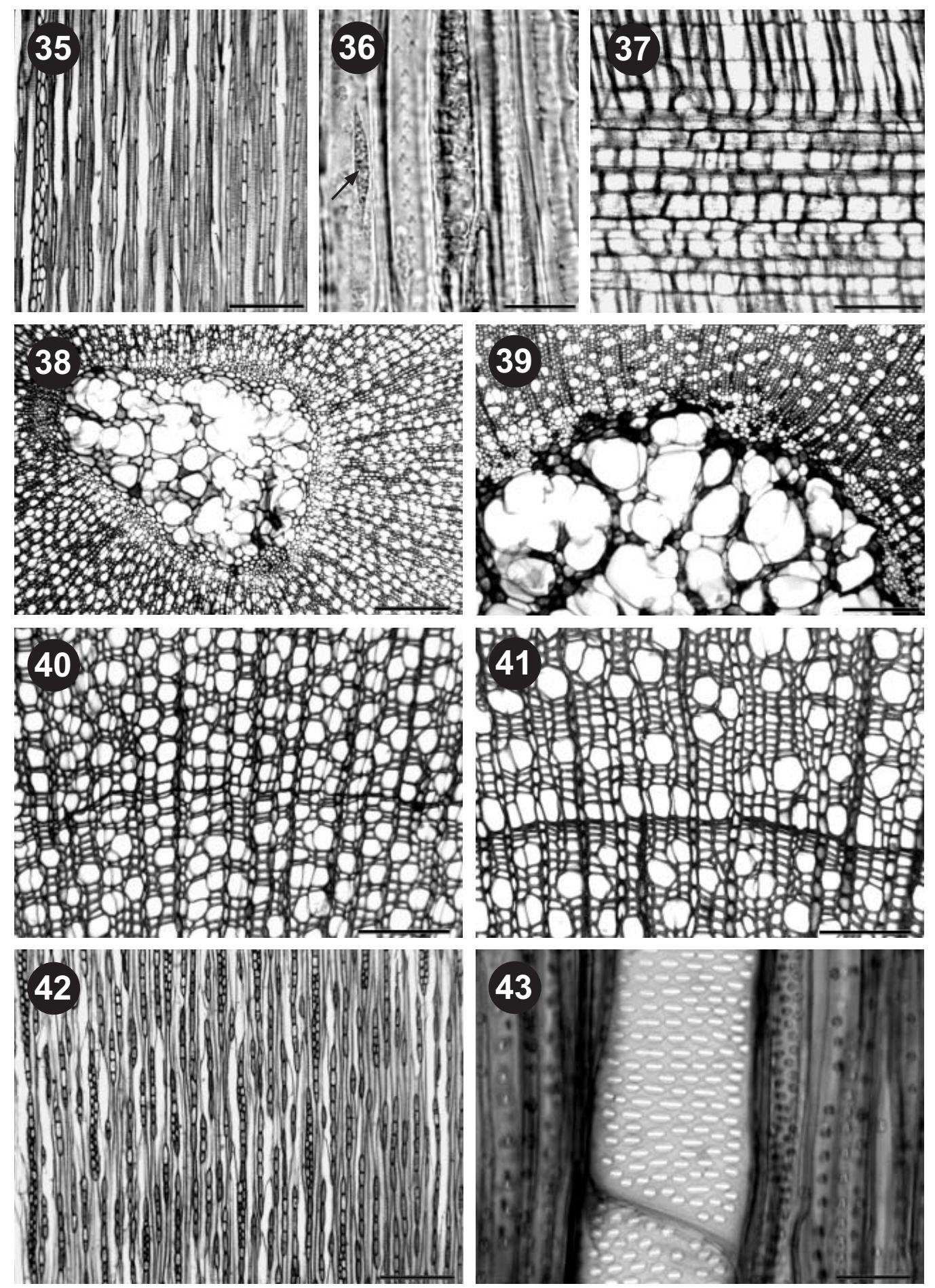

Figures 35-43. LM micrographs showing the wood structure of Gaultherieae and Andromedeae s.s. Fig. 35. Gaultheria rudis, TLS, narrow, high multiseriate ray at left. Scale bar $=200 \mu \mathrm{m}$. Fig. 36. Gaultheria shallon, TLS, living fibre with nucleus (arrow). Scale bar $=20 \mu \mathrm{m}$. Fig. 37. Gaultheria strigosa, RLS, procumbent and square body ray cells. Scale bar $=100 \mu \mathrm{m}$. Fig. 38. Andromeda polifolia, TS, strongly heterogeneous pith. Scale bar $=200 \mu \mathrm{m}$. Fig. 39. Zenobia pulverulenta, TS, strongly heterogeneous pith. Scale bar $=200 \mu \mathrm{m}$. Fig. 40. Andromeda polifolia, TS, narrow vessels with a high density. Scale bar $=100 \mu \mathrm{m}$. Fig. 41. Zenobia pulverulenta (E), TS, distinct growth ring, solitary vessels, very thin-walled fibres. Scale bar $=100 \mu \mathrm{m}$. Fig. 42. Zenobia pulverulenta (E), TLS, narrow, multiseriate rays. Scale bar $=200 \mu \mathrm{m}$. Fig. 43. Zenobia pulverulenta (E), TLS, mainly opposite vessel pitting. Scale bar $=20 \mu \mathrm{m}$. 
observed in libriform fibres of Andromeda polifolia and Zenobia pulverulenta (BR). Axial parenchyma scanty paratracheal, $2-4$ cells per parenchyma strand. Uniseriate rays always present, $110-(476)-1100 \mu \mathrm{m}$ high, consisting of upright cells, 7-(17)-26 rays $\mathrm{mm}^{-1}$. Multiseriate rays present in Zenobia pulverulenta, 2-seriate, $0-(3)-17$ rays $\mathrm{mm}^{-1}$, consisting of procumbent and square body ray cells and 1-3 rows of upright marginal ray cells, $450-(720)-1000 \mu \mathrm{m}$ high. Gummy deposits in ray cells. Prismatic crystals absent. Pith cells of two different forms: small groups of very large cells with thin walls clustered between smaller cells with thicker walls. No prismatic crystals in pith cells observed.

\section{DISCUSSION}

\section{CHARACTERISTIC FEATURES OF THE WOOD STRUCTURE of ANDROMEDEAE S.S., GAUltheRIEAE, LyONIEAE AND OXYDENDREAE}

A typical wood sample of the study group shows growth rings and a diffuse porosity. Vessels are mainly solitary, although some tangential vessel groupings are observed in most genera. The tangential diameter is narrow, usually ranging from 15 to $40 \mu \mathrm{m}$, and the vessel density usually ranges from 100 to 300 vessels $\mathrm{mm}^{-2}$. The length of the vessel elements is commonly between 350 and $800 \mu \mathrm{m}$. Vessels often have scalariform perforation plates, but exclusively simple perforations are observed in Lyonia jamaicensis; mixed simple and scalariform perforations are found in Agauria, Craibiodendron, Lyonia, Oxydendrum and Pieris, although usually one type dominates. Intervessel pits are mostly opposite or alternate, except in Agauria and Oxydendrum, where scalariform intervessel pitting is the main type. Vessel-ray pits are distinctly bordered, but sometimes simple in Oxydendrum (Fig. 6), and are similar to intervessel pitting, although more scalariform vesselray pitting is observed in some species of Agarista, Gaultheria, Lyonia and Pieris. Fibre-tracheids have distinctly bordered pits (3-6 $\mu \mathrm{m}$ in size) and very thin to thick walls. Helical thickenings in fibre-tracheids are seen in Gaultheria and Pernettya. Occasionally thin-walled libriform fibres, which are nearly always septate with few simple to indistinctly bordered pits, are observed in all species (except for Diplycosia heterophylla and Leucothoe grayana). Tracheids are always present and occur sparsely throughout the wood, with helical thickenings in several Gaultheria and Pernettya species. The axial parenchyma is scanty paratracheal, with a tendency to a diffuse-inaggregates distribution in Lyonia squamulosa and especially in L. jamaicensis (Fig. 14). Uniseriate rays consisting of upright cells are always present and occur in combination with heterocellular, multiseriate rays, which consist of exclusively procumbent or procumbent and square body ray cells, and one to several rows of square to upright marginal ray cells. Exclusively uniseriate rays are present in the juvenile stems of Andromeda polifolia and Tepuia venusta. Multiseriate rays are in general 2-5 cells wide. In Agauria and Agarista, however, 5-9-seriate rays are observed (Fig. 15). The height of the uniseriate rays mostly ranges from 200 to $1000 \mu \mathrm{m}$, whereas multiseriate rays are much higher, mostly between 500 and $3000 \mu \mathrm{m}$, with the highest rays in Agarista, Agauria and Gaultheria. Gummy deposits (possibly tannins) are frequently noticed in the ray cells (Fig. 16). Prismatic crystals occur in chambered axial parenchyma cells of Oxydendrum (Figs 7,8) and several Lyonia species (Fig. 19), and in ray cells of Agarista populifolia and A. bracamorensis (Fig. 20).

Our wood anatomical observations largely agree with earlier descriptions and only minor differences can be found (Cox, 1948; Metcalfe \& Chalk, 1950; Suzuki \& Noshiro, 1988). For example, the presence of relatively narrow vessels and a unique ray type in Agauria as mentioned by Cox (1948) are probably due to the juvenile nature of the wood examined. Moreover, some features that were not recorded previously include the presence of simple perforations and helical thickenings in vessel elements of Lyonia species, multiseriate rays higher than $1 \mathrm{~mm}$ in several genera, sheath cells in some species of Agarista, Diplycosia, Leucothoe and Pernettya, and the occurrence of prismatic crystals in Agarista, Lyonia and Oxydendrum. We also noticed few septate and/or non-septate libriform fibres in nearly all genera. The wood samples preserved in FAA (Andromeda, Gaultheria, Leucothoe, Pieris and Zenobia) demonstrated the presence of nuclei within libriform fibres, thus indicating that a living protoplast occurs in these cells (Fig. 36). It is very likely that septate libriform fibres in Oxydendrum and in other genera contain nuclei, because of the general acceptance that septate fibres retain their living protoplasts much longer than fibre-tracheids and tracheids. Likewise, living fibres are also observed within the closely related Vaccinieae (Braun, 1961; Fahn \& Leshem, 1962; Giebel, 1983; our observations). However, this can only be determined when looking at non-dried, well-preserved wood samples.

\section{PhylOGENETIC WOOD ANATOMY}

Although most genera studied cannot be defined by wood anatomical features as such, the secondary xylem provides useful information in confirming or negating already proposed relationships because certain features appear to be consistent at the tribal level. Although the generic relationships within the 
tribes are incompletely understood, we have plotted five important wood anatomical features of the study group on a tree, which is based on the molecular phylogenetic studies of Kron \& Judd (1997), Kron et al. (1999) and Powell \& Kron (2001). The branches of this tree represent all genera examined by us plus one branch forming the Vaccinieae. The five wood characters are the type of vessel perforation plate (Fig. 44), the arrangement of vessel-ray pitting (Fig. 45), the mean height of multiseriate rays (Fig. 46), the shape of body ray cells in multiseriate rays (Fig. 47), and the occurrence and location of prismatic crystals (Fig. 48). These features are selected because of their apparent consistency at the generic and/or tribal level. As for the height of multiseriate rays, four character states are defined based on the overall measurements in the study group as well as on data in Vaccinieae (Table 2; our observations): (1) below $400 \mu \mathrm{m}$, (2) between 400 and $1000 \mu \mathrm{m}$, (3) between 1000 and $3000 \mu \mathrm{m}$, and (4) above $3000 \mu \mathrm{m}$. Although there are some genera that cannot be easily categorized into one of these four character states, the character states proposed appear to correspond well with generic and tribal delimitations. A detailed discussion of the wood anatomical
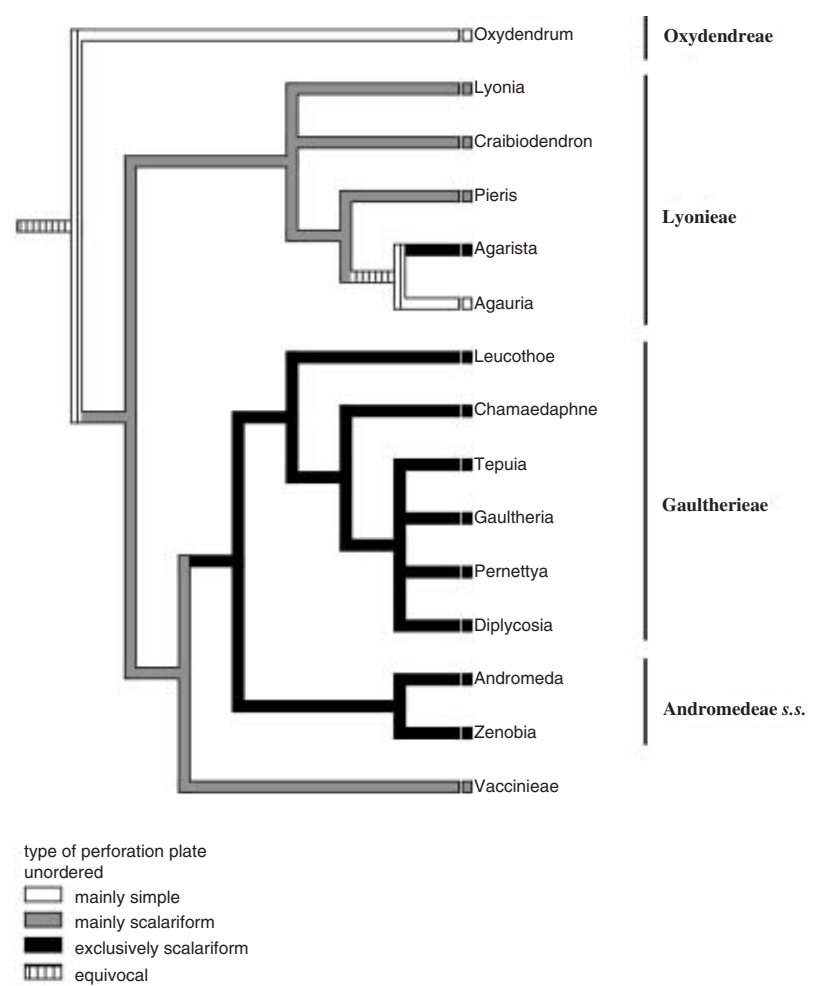

Figure 44. Type of vessel perforation plates in the wood of Andromedeae s.s., Gaultherieae, Lyonieae and Oxydendreae plotted on the molecular phylogeny suggested by Kron \& Judd (1997), Kron et al. (1999) and Powell \& Kron (2001). variation within and between the various tribes is presented below.

Oxydendrum takes the most basal position within Vaccinioideae. Owing to its possession of nearly exclusively simple perforations (Figs 7, 44), mainly scalariform vessel-ray pits that are sometimes simple (Fig. 6), conspicuous helical thickenings (Fig. 5), rare occurrence of low, uniseriate rays, and numerous, low multiseriate rays (Fig. 46), and prismatic crystals in chambered axial parenchyma cells (Figs 7, 8, 48), $O x y$ dendrum can clearly be defined on the basis of wood anatomical data alone. Besides these wood anatomical characters, there are also other anatomical features supporting the isolated position of Oxydendrum (Palser, 1952; Stevens, 1971). Compared with more primitive Ericaceae clades, it can be suggested that the presence of low and narrow multiseriate rays represents primitive features within Vaccinioideae (Lens et al., 2003). However, these features do not only occur in Oxydendrum: low and narrow multiseriate rays are also found in some samples of Gaultheria (Fig. 35). By contrast, the presence of scalariform vessel-ray pits with strongly reduced borders, sometimes also observed in Agauria, probably represents a derived

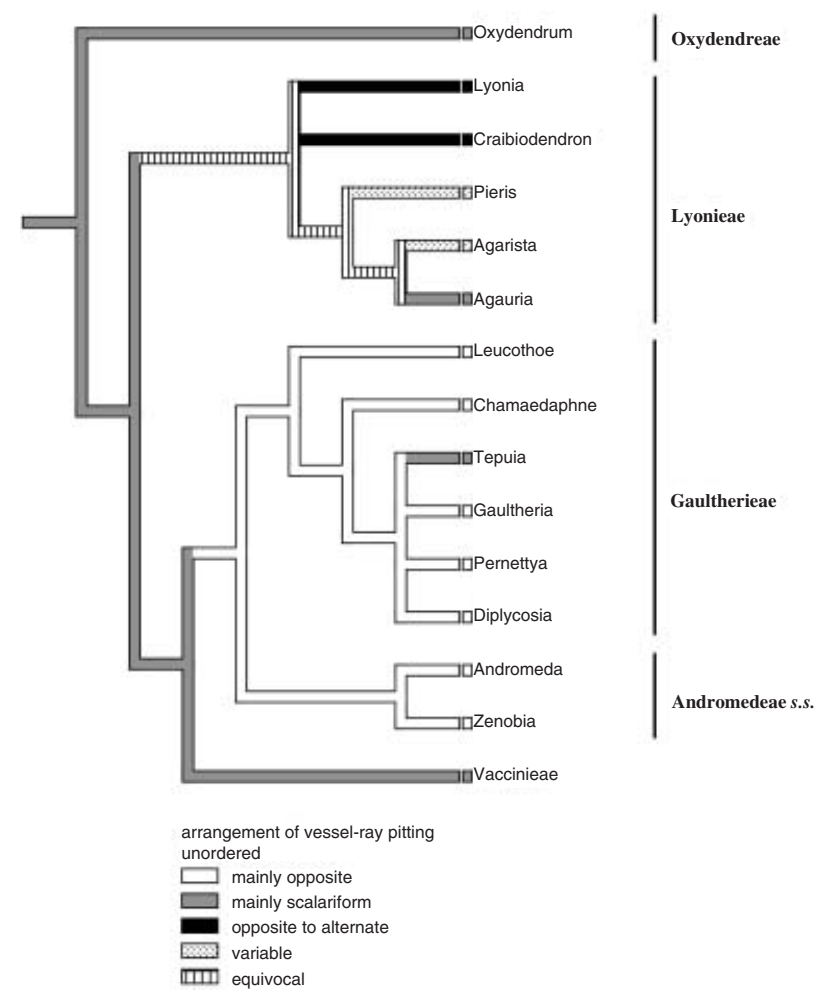

Figure 45. Arrangement of vessel-ray pitting in the wood of Andromedeae s.s., Gaultherieae, Lyonieae and Oxydendreae plotted on the molecular phylogeny suggested by Kron \& Judd (1997), Kron et al. (1999) and Powell \& Kron (2001). 


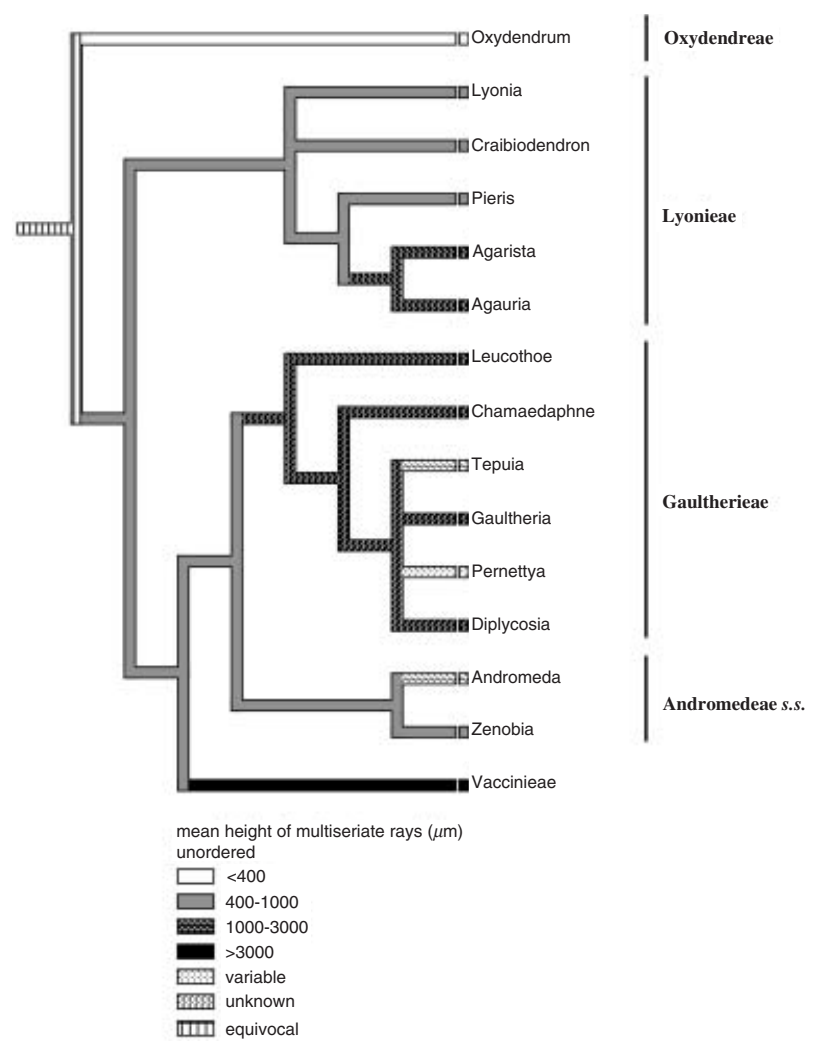

Figure 46. Mean height of multiseriate rays in the wood of Andromedeae s.s., Gaultherieae, Lyonieae and Oxydendreae plotted on the molecular phylogeny suggested by Kron \& Judd (1997), Kron et al. (1999) and Powell \& Kron (2001).

feature because this is commonly observed in Vaccinieae (our observations).

The tribe Lyonieae is characterized by mainly scalariform vessel perforations (Fig. 44; except for Agauria, see Fig. 21, and Lyonia jamaicensis), mainly opposite to alternate vessel-ray pitting (Figs 26, 45), rather low, multiseriate rays between 400 and $1000 \mu \mathrm{m}$ high (except for Agauria and Agarista) showing procumbent body ray cells (Figs 17, 18, 47), and the presence of prismatic crystals in axial parenchyma cells of some Lyonia species (Fig. 19). Two features that are not observed in other Lyonieae, namely the presence of scalariform vessel-ray pitting (Figs 24, 25), as well as broad and high rays (sometimes even higher than $3000 \mu \mathrm{m}$, Fig. 15), seem to support the close relationship between Agauria and Agarista. The major difference between the African Agauria and the neotropical Agarista is the distribution of mainly simple vessel perforation plates in Agauria (Fig. 21) and the exclusively scalariform perforations in Agarista (Fig. 22), but this could be due to the various ecological conditions. Minor differences include the presence of helical thickenings in vessel

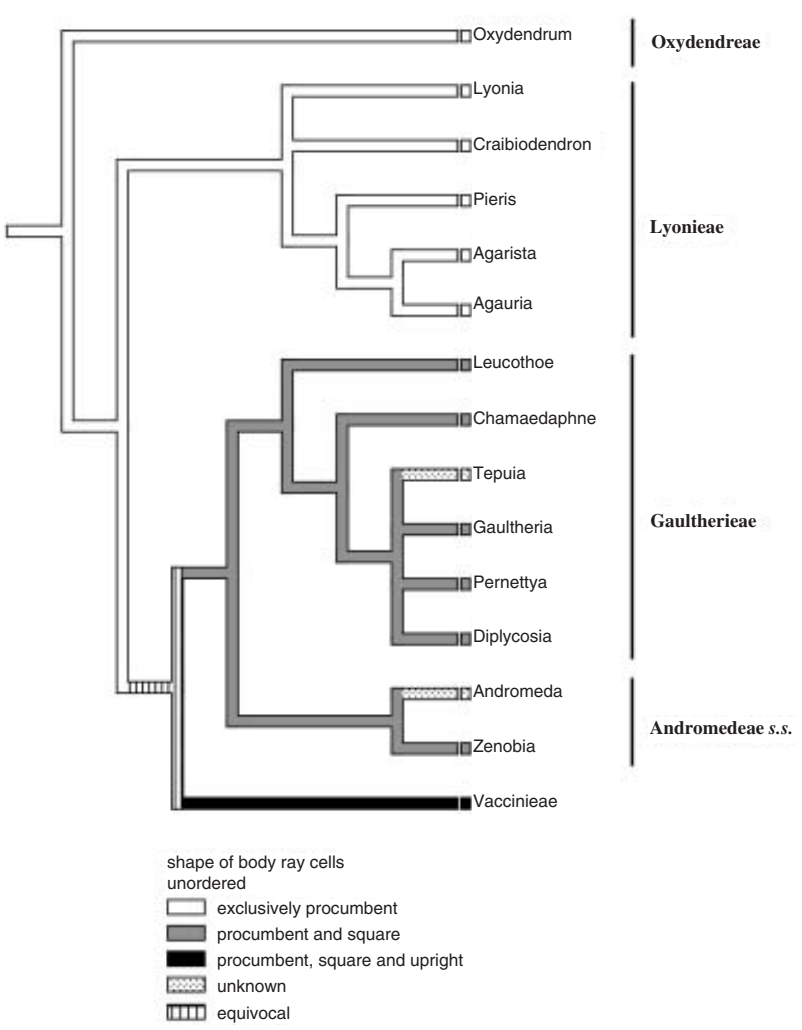

Figure 47. Shape of the body ray cells in multiseriate rays in the wood of Andromedeae s.s., Gaultherieae, Lyonieae and Oxydendreae plotted on the molecular phylogeny suggested by Kron \& Judd (1997), Kron et al. (1999) and Powell \& Kron (2001).

elements, exclusively bordered vessel-ray pitting, and the occurrence of some square body ray cells in Agarista. However, the scarce presence of square body ray cells in Agarista populifolia, A. pulchella and A. uleana may be due to the juvenile nature of the wood (see below). Thus, wood anatomical data support the inclusion of Agauria as a section within Agarista as mentioned by Stevens (1970) and Judd (1984). Another species with a prominent wood structure appears to be Lyonia jamaicensis (Fig. 14). This species shows exclusively simple perforations, rounded vessel outlines, exclusively alternate vessel-ray pitting, thick-walled fibres with small, indistinctly to distinctly bordered fibre pits $(3 \mu \mathrm{m}$ in size), and diffuse-in-aggregates axial parenchyma cells, with 6-9 cells per strand. However, the presence of prismatic crystals in chambered axial parenchyma cells links this species with other Lyonia species of section Lyonia: three of the four species of section Lyonia studied, namely L.heptamera, L. jamaicensis (Fig. 19) and L. squamulosa, show prismatic crystals in axial parenchyma cells, whereas other Lyonia samples lack crystals in their wood. The 


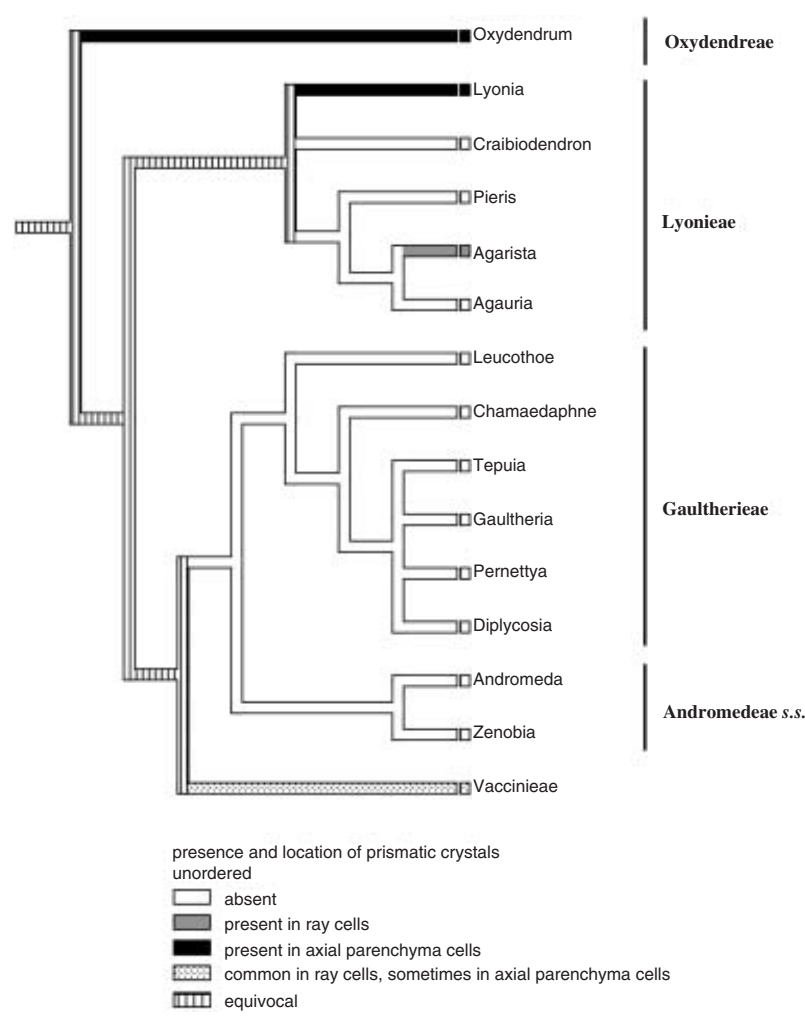

Figure 48. Presence and location of prismatic crystals in the wood of Andromedeae s.s., Gaultherieae, Lyonieae and Oxydendreae plotted on the molecular phylogeny suggested by Kron \& Judd (1997), Kron et al. (1999) and Powell \& Kron (2001).

presence of scalariform vessel-ray pitting within Lyonieae may support the sister relationship between the genera Pieris and Agarista (incl. Agauria), whereas the alternate vessel-ray pits could link Craibiodendron with Lyonia, as has been pointed out by an analysis of combined morphological and mat $\mathrm{K}$ data (Kron \& Judd, 1997).

The secondary xylem of Gaultherieae differs from Lyonieae by the presence of mainly opposite vessel-ray pitting (Fig. 45), relatively rare (often between 0 and 4 rays $\mathrm{mm}^{-2}$ ), often high, multiseriate rays (between 1000 and $3000 \mu \mathrm{m}$; Fig. 46) with procumbent and square body rays cells (Fig. 37), and the absence of prismatic crystals (Fig. 48). In particular, the shape of the body ray cells within one multiseriate ray may be an important character to distinguish these two tribes from each other (Fig. 47). Heterocellular ray bodies are observed in all Gaultherieae genera, and this type of body ray cell is only seen outside Gaultherieae in Zenobia pulverulenta, Pieris japonica (L. Rothkegel) and in some Agarista species. This may therefore form an argument to include Chamaedaphne, which was formerly considered to be isolated, within Gaulth- erieae. However, it is worth mentioning that the shape of body ray cells may also depend on the maturity/size of the wood samples studied: in shrubs and small trees, in particular, a higher percentage of upright body ray cells is usually seen near the pith and procumbent cell shapes are more abundant closer to the cambium. Thus, this ontogenetic variation may play a significant role in the study group because the mean diameter of Gaultherieae wood samples studied, all derived from shrubby species, is much smaller than that for the wood samples of Lyonieae, for which shrubs as well as small trees were studied. However, the two Gaultherieae samples with the largest stem diameter, i.e. Gaultheria anastomosans $(27 \mathrm{~mm})$ and G. erecta (Kw 11654, $26 \mathrm{~mm}$ ), also show square body ray cells, indicating that the structure of multiseriate rays has a phylogenetic signal within the study group. Another feature that could be influenced by ontogenetic variation is the length of tracheary elements. Indeed, the mean length of vessel elements, fibre-tracheids and tracheids in Gaultherieae (respectively 547,576 and $761 \mu \mathrm{m}$ ) is somewhat lower than in Lyonieae (respectively 596, 694 and $921 \mu \mathrm{m}$ ). This difference in length could also be influenced by their habit (shrubs vs. small trees), an important factor in the wood of Vaccinioideae that will be treated elsewhere.

The wood structure of Leucothoe, which is the most primitive genus of Gaultherieae, is typical of this tribe, except for the absence of helical thickenings in the vessel elements. Based on the presence of mainly opposite vessel-ray pitting, the absence of conspicuous helical thickenings in vessel elements, and the smaller width and height of the multiseriate rays, it is clear that Leucothoe is not closely related to Agarista, with which it was formerly associated (Sleumer, 1959). Leucothoe grayana, the only species of section Eubotryoides, is very similar to the other two Leucothoe species observed, which are representatives of section Leucothoe, and only small differences can be noticed, such as the presence of occasional helical thickenings in the tails of vessel elements, the thin- to thick-walled fibres, and the absence of libriform fibres in L. grayana. Chamaedaphne calyculata, which is nested at the basis of the wintergreen group (including Diplycosia, Gaultheria, Pernettya and Tepuia), is characterized by several (mainly quantitative) features, namely the small length of the tracheary elements (vessel elements, fibres, tracheids), the very high density of vessels (Fig. 28) and uniseriate rays, and the lack of septate libriform fibres, although some of these features are probably related to its northern boreal distribution. The wood anatomical variation of the taxa studied within the wintergreen group is rather homogeneous. However, the young twig of Tepuia venusta studied, an endemic to the tepuis of the Venezuelan Guayana, shows some atypical fea- 
tures for this wintergreen group, such as the presence of very narrow vessel elements, a very high vessel density, thick fibre walls (Fig. 34), non-septate libriform fibres and abundant exclusively uniseriate rays. It is interesting to note that some of these features are also found in the wood of Chamaedaphne, although the ecological conditions of both genera are rather different. Furthermore, the wood of Pernettya and Gaultheria is very similar, which may support the results of Middleton \& Wilcock (1990) and Powell \& Kron (2001), but provides less evidence to consider the two genera as distinct entities (Luteyn, 1995a,b). Indeed, Gaultheria and Pernettya are the only two genera that are characterized by the presence of helical thickenings throughout the fibres. Although Diplycosia is also nested within Gaultheria according to molecular data (Powell \& Kron, 2001), the only representative of Diplycosia studied by us differs from Gaultheria by its high number of bars per scalariform perforation plates, the lack of helical thickenings and libriform fibres, and the occurrence of thick-walled fibres (Fig. 31). More wood samples of Diplycosia species need to be observed to comment on possible relationships between Diplycosia and Gaultheria.

Morphological synapomorphies for the two genera of the tribe Andromedeae s.s. have not yet been discovered, but molecular data clearly seem to support this clade (Kron et al., 2002). From a wood anatomical point of view, Andromedeae s.s. is a homogeneous tribe that is similar to its sister tribe Gaultherieae. It is defined by the presence of exclusively scalariform perforation plates, mainly opposite vessel-ray pitting (Fig. 43), relatively low, multiseriate rays (Fig. 42) with procumbent and square body ray cells (although absent in Andromeda, but this is probably due to the juvenile wood studied), presence of non-septate libriform fibres, lack of prismatic crystals (Fig. 48) and the presence of a conspicuously heterogeneous pith structure (Figs 38, 39). Apparently, the wood structure of Gaultherieae only differs from Andromedeae s.s. by the mainly septate libriform fibres and higher multiseriate rays (Fig. 46) in Gaultherieae.

\section{WOOD ANATOMICAL COMPARISON WITH OTHER ERICACEAE S.L.}

The wood structure of the tribes Andromedeae, Gaultherieae, Lyonieae and Oxydendreae show many similarities with other Ericaceae s.l. Examples include the diffuse-porosity, narrow and solitary vessels with an angular vessel outline, high vessel frequency, scalariform and/or simple vessel perforations, tracheids, distinctly bordered fibre pits (fibre-tracheids), scarcely distributed axial parenchyma and the combination of uniseriate rays with less common multiseriate rays. The study group especially corresponds with the tribe
Vaccinieae, and with the subfamily Styphelioideae, which is the sister group of Vaccinioideae according to molecular data (Kron et al., 2002). As has already been mentioned by Lens et al. (2003), the presence of wide and high multiseriate rays, both of which are nearly absent outside Styphelioideae and Vaccinioideae, may support the relationship between both subfamilies. In addition, the sporadic occurrence of libriform fibres and the presence of crystal-bearing axial parenchyma cells is found in both subfamilies, but these two features also occur in the distantly related subfamily Arbutoideae (our observations).

By contrast, there are some wood anatomical features that enable us to distinguish between Andromedeae sensu Stevens and Vaccinieae. The most important difference is the abundant presence of procumbent body ray cells in most tribes studied here (Figs 17, 18), whereas Vaccinieae are largely characterized by square and upright body ray cells (Fig. 47; our obserations). Procumbent to square body ray cells, however, are characteristic of Gaultherieae (Fig. 47). Other distinguishing features are the height of the multiseriate rays and the presence of prismatic crystals in ray cells: very tall rays of $3000 \mu \mathrm{m}$ or more and prismatic crystals in ray cells are common in Vaccinieae (Fig. 48; our observations) but rare in other Vaccinioideae.

\section{PITH CHARACTERS}

The pith structure in Andromedeae sensu Stevens shows a significant variation and allows us to define three types (Fig. 49; Judd, 1979; Kron et al., 1999; our observations): (1) a homogeneous pith type with thinor thick-walled cells, all of more or less the same size (Fig. 28), (2) a heterogeneous pith type with small, thick-walled cells scattered between larger, thinwalled cells (Figs 9, 27) and (3) a Calluna-type with small thin- or thick-walled cells at the perifery surrounding a pith cavity (Fig. 10). In this study, we were able to define a fourth pith type, namely a very conspicuously heterogeneous structure in the two genera of Andromedeae s.s.: the very small, thickwalled pith cells strongly contrast with the very large, thin-walled cells, giving the pith structure a reticulate appearance (Figs 38, 39). This 'strongly' heterogeneous pith type could be a first morphological synapomorphy for the Andromedeae s.s. The 'normal', heterogeneous pith type, which is not reticulate at all, is found in representatives of Lyonieae (Pieris and Agauria) and Gaultherieae (Gaultheria and Pernettya). The homogeneous pith type characterizes some genera of Lyonieae (Lyonia and Craibiodendron) and Gaultherieae (Chamaedaphne, Tepuia and Diplycosia). Besides the similar vessel-ray pitting between Lyonia and Craibiodendron, the homoge- 


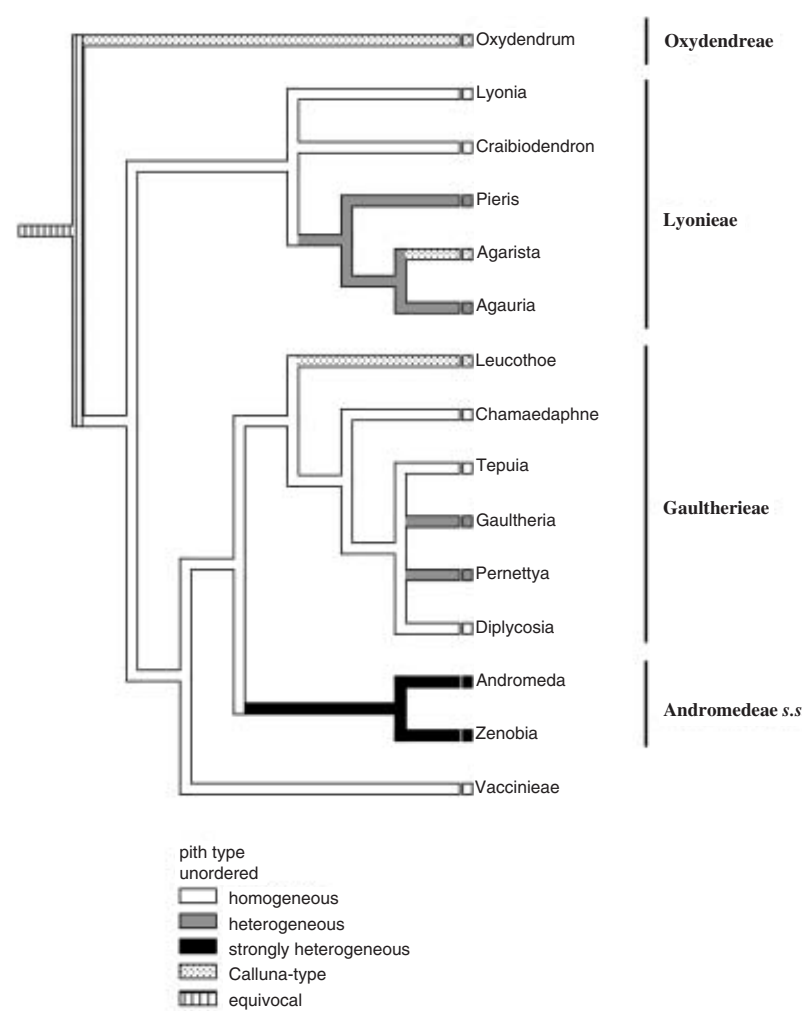

Figure 49. Pith types in Andromedeae s.s., Gaultherieae, Lyonieae and Oxydendreae plotted on the molecular phylogeny suggested by Kron \& Judd (1997), Kron et al. (1999) and Powell \& Kron (2001).

neous pith type in both genera may give an additional support for their close relationship. The Calluna-type is present in Oxydendrum (Oxydendreae), Agarista (excluding Agauria; Lyonieae) and Leucothoe section Leucothoe (Gaultherieae) (Judd, 1979; Kron et al., 1999).

The different pith types as outlined above become even more striking when compared with the large tribe Vaccinieae, which only have the homogeneous type (Fig. 49). The same pith type is also characteristic of the subfamily Styphelioideae, except for Richea and Dracophyllum (Richeeae), which show a strongly heterogeneous pith type similar to the Andromedeae s.s. (Lens et al., 2003).

\section{CONCLUSIONS}

Several features in the secondary xylem of Andromedeae s.s., Gaultherieae, Lyonieae and Oxydendreae show a taxonomic significance at the tribal level. In particular, the type of vessel perforation plate, arrangement of vessel-ray pitting, height of multiseriate rays, shape of body ray cells, and the distribution and location of prismatic crystals may be useful in assigning an unknown specimen to one of the four tribes studied. Living fibres are observed in Andromedeae s.s., Lyonieae and Gaultherieae, and seem to characterize the subfamily Vaccinioideae. It is also demonstrated that the pith structure within Oxydendreae and Andromedeae s.s. is consistent, but there is much more variation in Lyonieae and Gaultherieae.

\section{ACKNOWLEDGEMENTS}

The National Botanic Garden of Belgium (BR) and the curators of the wood collection of Leiden (L), Kew $(\mathrm{Kw})$, Madison (MADw), Utrecht (Uw) and Tervuren (Tw) are greatly acknowledged for their supply of wood samples. Special thanks go to Dr Luteyn (The New York Botanical Garden), Dr Wallace (Rancho Santa Ana Botanic Garden) and Miss Fiona Inches (Royal Botanic Gardens, Edinburgh) for sending wood material. We thank Miss Anja Vandeperre (K.U.Leuven) for technical assistance and Marcel Verhaegen (National Botanic Garden of Belgium) for the preparation of SEM images. This work was financially supported by research grants from the K.U.Leuven (OT/01/25), the Fund for Scientific Research Flanders (Belgium) (G.104.01, 1.5.069.02, 1.5.061.03). S.J. is a postdoctoral fellow of the Fund for Scientific Research - Flanders (Belgium) (F.W.O. - Vlaanderen).

\section{REFERENCES}

Baas P. 1979. The peculiar wood structure of Vaccinium lucidum (Bl.) Miq. (Ericaceae). International Association of Wood Anatomists Bulletin 1979/1: 11-16.

Baas P. 1986. Terminology of imperforate tracheary elements - in defence of libriform fibres with minutely bordered pits. International Association of Wood Anatomists Bulletin 7: 8286.

Braun HJ. 1961. The organisation of the hydrosystem in the stemwood of trees and shrubs. International Association of Wood Anatomists New Bulletin 2: 2-9.

de Candolle ALP. 1839. Prodomus Systematis Naturalis Regni Vegetabilis, Vol. 7. Paris.

Carlquist S. 1988. Tracheid dimorphism: a new pathway in evolution of imperforate tracheary elements. Aliso 12: 103118.

Carlquist S. 2001. Comparative wood anatomy. Systematic, ecological, and evolutionary aspects of dicotyledon wood, 2nd edn. Berlin: Springer-Verlag.

Cox HT. 1948. Studies in the comparative anatomy of the Ericales. II. Ericaceae-subfamily Arbutoideae. American Midland Naturalist 40: 493-516.

Drude O. 1897. Ericaceae. In: Engler A, Prantl K, eds. Die Natürlichen Pflanzenfamilien, Vol. 4. Leipzig: Engelman.

Fahn A, Leshem B. 1962. Wood fibres with living protoplasts. New Phytologist 62: 91-98.

Giebel K. 1983. Vegetative anatomy. In: Luteyn JL, ed. Flora Neotropica. Monograph 35. Ericaceae Part I, Cavendishia. New York: New York Botanical Garden, 4-12. 
Hooker JD. 1876. Ericaceae. In: Bentham G, Hooker JD, eds. Genera Plantarum, Vol. 2. London: Reeve.

IAWA Committee. 1989. IAWA list of microscopic features for hardwood identification. International Association of Wood Anatomists Bulletin, New Series 10: 219-332.

Jansen S, Kitin P, De Pauw H, Idris M, Beeckman H, Smets E. 1998. Preparation of wood specimens for transmitted light microscopy and scanning electron microscopy. Belgian Journal of Botany 131: 41-49.

Judd WS. 1979. Generic relationships in the Andromedeae (Ericaceae). Journal of the Arnold Arboretum 60: 447-503.

Judd WS. 1984. A taxonomic revision of the American species of Agarista (Ericaceae). Journal of the Arnold Arboretum 65: 255-342.

Kron KA, Judd WS. 1997. Systematics of the Lyonia group (Andromedeae, Ericaceae) and the use of species as terminals in higher-level cladistic analyses. Systematic Botany 22: 479-492.

Kron KA, Judd WS, Crayn DM. 1999. Phylogenetic analyses of Andromedeae (Ericaceae subfam. Vaccinioideae). American Journal of Botany 86: 1290-1300.

Kron KA, Judd WS, Stevens PF, Anderberg AA, Crayn DM, Gadek PA, Quinn CJ, Luteyn JL. 2002. A phylogenetic classification of Ericaceae: molecular and morphological evidence. Botanical Review 68: 335-423.

Lens F, Gasson P, Smets E, Jansen S. 2003. Comparative wood anatomy of epacrids (Styphelioideae, Ericaceae s.1.). Annals of Botany 91: 835-857.

Luteyn JL. 1995a. Pernettya. In: Luteyn JL, ed. Flora neotropica. Monograph 66. Ericaceae Part II, The superiorovaried genera. New York: New York Botanical Garden, 365-383.

Luteyn JL. 1995b. Gaultheria. In: Luteyn JL, ed. Flora neo- tropica. Monograph 66. Ericaceae Part II, The superior-ovaried genera. New York: New York Botanical Garden, 384-488.

Metcalfe CR, Chalk L. 1950. Anatomy of the dicotyledons, 2nd edn, Vol. 2. Oxford: Clarendon Press.

Middleton DJ, Wilcock CC. 1990. A critical examination of the status of Pernettya as a genus distinct from Gaultheria. Edinburgh Journal of Botany 47: 291-301.

Palser BF. 1952. Studies of floral morphology in Ericales. III. Organography and vascular anatomy of several species of Arbuteae. Phytomorphology 4: 335-354.

Powell EA, Kron KA. 2001. An analysis of the phylogenetic relationships in the wintergreen group (Diplycosia, Gaultheria, Pernettya, Tepuia; Ericaceae). Systematic Botany 26: 808-817.

Sleumer H. 1959. Studien über die Gattung Leucothoë D.Don. Botanische Jahrbücher 78: 435-480.

Stern WL. 1988. Index Herbariorum. Institutional wood collections of the world, 3rd edn. International Association of Wood Anatomists Bulletin new Series 9: 204-252.

Stevens PF. 1970. Agauria and Agarista: an example of tropical transatlantic affinity. Notes from the Royal Botanic Garden at Edinburgh 30: 341-359.

Stevens PF. 1971. A classification of the Ericaceae: subfamilies and tribes. Botanical Journal of the Linnean Society 64: $1-53$.

Stevens PF. 1995. Familial and infrafamilial relationships. In: Luteyn JL, ed. Flora neotropica. Monograph 66. Ericaceae Part II, The superior-ovaried genera. New York: New York Botanical Garden, 1-10.

Suzuki M, Noshiro S. 1988. Wood structure in Himalayan plants. In: Ohba H, Malla SB, eds. Himalayan plants, Vol. 1. Bulletin of the National Science Museum, Tokyo 31: 341379. 